
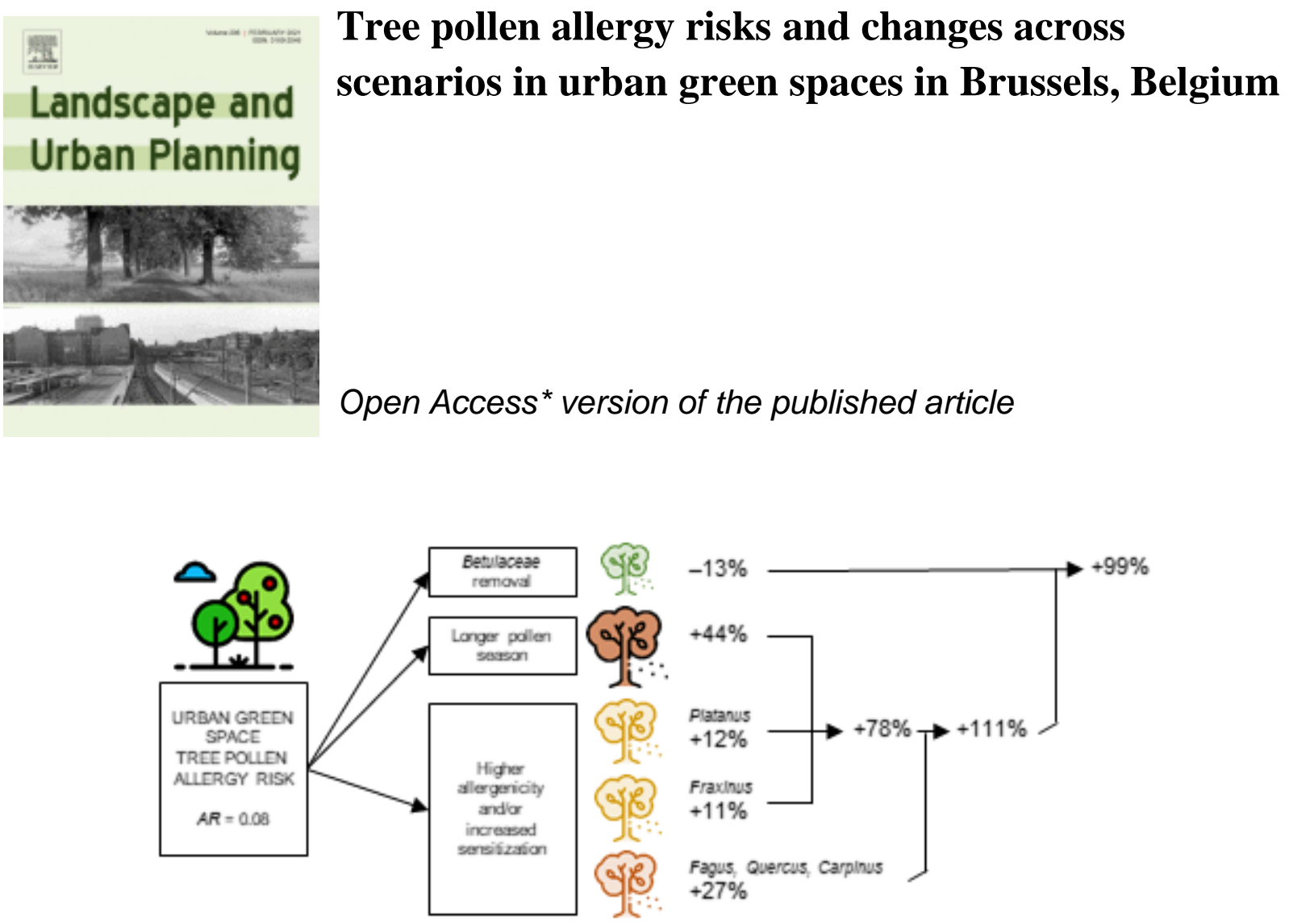

\title{
Citation:
}

Aerts R., Bruffaerts N., Somers B. Demoury C., Plusquin M., Nawrot T.S., Hendrickx M. 2021. Tree pollen allergy risks and changes across scenarios in urban green spaces in Brussels,

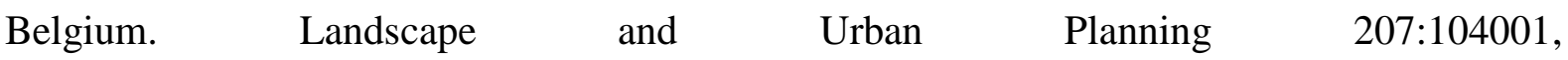
https://doi.org/10.1016/j.landurbplan.2020.104001

*Elsevier authorized the authors to post this revised personal version of the text of the final journal article on the author's institutional server, incorporating the complete citation and with a link to the Digital Object Identifier (DOI) of the article.

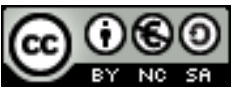

Creative Commons Attribution-Noncommercial-Share Alike 2.0 Belgium License

Permissions beyond the scope of this license may be available at http://www.elsevier.com/wps/find/authorsview.authors/copyright\#whatrights 


\section{Tree pollen allergy risks and changes across scenarios in urban green spaces in Brussels, Belgium}

Raf AERTS $^{\mathrm{a}, \mathrm{b}, \mathrm{c}, \mathrm{d}, \mathrm{e}}$, Nicolas BRUFFAERTS ${ }^{\mathrm{b}}$, Ben SOMERS ${ }^{\mathrm{e}}$, Claire DEMOURY ${ }^{\mathrm{a}}$, Michelle PLUSQUIN $^{\mathrm{d}}$, Tim S. NAWROT ${ }^{\mathrm{d}, \mathrm{f}}$, Marijke HENDRICKX ${ }^{\mathrm{b}}$

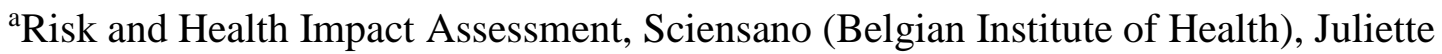
Wytsmanstraat 14, BE-1050 Brussels, Belgium

raf.aerts@sciensano.be, claire.demoury@sciensano.be

${ }^{b}$ Mycology and Aerobiology, Sciensano (Belgian Institute of Health), Juliette Wytsmanstraat 14, BE-1050 Brussels, Belgium

raf.aerts@sciensano.be, marijke.hendrickx@sciensano.be, nicolas.bruffaerts@sciensano.be

${ }^{c}$ Division Ecology, Evolution and Biodiversity Conservation, University of Leuven (KU

Leuven), Kasteelpark Arenberg 31-2435, BE-3001 Leuven, Belgium

raf.aerts@kuleuven.be

${ }^{\mathrm{d}}$ Center for Environmental Sciences, University of Hasselt, Agoralaan D, BE-3590

Diepenbeek, Hasselt, Belgium

raf.aerts@uhasselt.be, michelle.plusquin@uhasselt.be, tim.nawrot@uhasselt.be

eDivision Forest, Nature and Landscape, University of Leuven (KU Leuven), Celestijnenlaan 200E-2411, BE-3001 Leuven, Belgium

raf.aerts@kuleuven.be, ben.somers@kuleuven.be

${ }^{\mathrm{f}}$ Center for Environment and Health, Department of Public Health and Primary Care, University of Leuven, Herestraat 49-706, BE-3000 Leuven, Belgium tim.nawrot@kuleuven.be

Address correspondence to R. Aerts, Sciensano, Juliette Wytsmanstraat 14, BE-1050 Brussels. Telephone +32 264250 63. Email: raf.aerts@sciensano.be 


\section{Highlights}

- We studied allergy risks (AR) of 18 green spaces in Brussels, Belgium

- We examined present and possible future AR across contrasting scenarios

- Increased tree allergenic potential resulted in 11-27\% higher AR

- Increased pollen season duration resulted in $44 \%$ higher AR

- $\quad$ AR increased by $99 \%$ in combined scenarios despite preventive tree removal 


\section{Abstract}

Urban green spaces may improve human health and well-being. However, green spaces may also emit allergenic pollen and these may trigger asthma, allergic disease, and respiratory infections. How allergy risks in green spaces may be modified by environmental change is still not widely understood.

This study analyzed tree inventory data of 18 urban green spaces (5940 trees; 278 taxa; 93 ha) in the Brussels Capital Region, Belgium. We investigated present tree pollen allergy risk (AR) and changes in AR driven by changes in tree species composition, allergenic potential and pollen season duration. AR was estimated by calculating the allergenicity index $I_{U G Z A}$ (range $0-1,1$ worst) for the present situation and 13 scenarios.

The average AR was 0.08 (SD 0.05; range 0.002-0.17). The AR increased by $11-27 \%$ in increased allergenic potential scenarios, and by $44 \%$ in the increased pollen season duration scenario. Preventive removal of birch, hazel and alder reduced the AR by $13 \%$. The AR increased by $99-111 \%$ in combined scenarios with and without preventive removal of the main allergenic taxa.

These findings indicate that tree pollen allergy risks could considerably rise when ongoing environmental changes lead to a combination of longer pollen seasons, increased pollen allergen potency, and increased sensitization for one or more species. The preventive removal of the main allergenic tree species cannot sufficiently counter allergy risks caused by other species and that are amplified by environmental change, highlighting the importance of careful tree species selection in urban green space policy and planning. 


\section{Keywords}

Allergy risk scenarios; Allergenic trees; Index of allergenicity; Urban green areas; Urban parks; Climate change

\section{Glossary}

Urban green space tree Relative risk of an urban green space to provoke allergic

pollen allergy risk (AR) symptoms, compared to a green space with the highest possible density of the most allergenic tree species growing in optimal conditions (e.g. homogeneous birch forest)

Tree allergenicity Contribution of an individual tree to the AR of a green space

Allergenic potential (AP) A combination of pollen allergen potency and allergen sensitization of the population that determines the allergenicity of tree species

Pollen allergen potency The amount of allergens measured as mass per pollen grain 


\section{Introduction}

Urban green spaces may improve human health and well-being, for example by improving social cohesion, by promoting physical activity, or by reducing noise, heat and other environmental stress (James, Banay, Hart, \& Laden, 2015; van den Bosch \& Sang, 2017;

Collins et al., 2020). Trees in urban green spaces are considered to be among the best naturebased solutions for a number of important challenges in the urban environment: trees ameliorate the urban microclimate and reduce the urban heat island effect, trees intercept precipitation and help to prevent peak water runoff, and trees help to mitigate the effects of the climate crisis by capturing and storing carbon (Roy, Byrne, \& Pickering, 2012; Salmond et al., 2016). As a result, trees often emerge as the drivers of the numerous health benefits that are associated with urban green space, including improved mental health (Aerts et al., 2020), lower allergen sensitization rates (Gernes et al., 2019), lower odds of diabetes and hypertension (Astell-Burt \& Feng, 2019), improved childhood respiratory health (de Oliveira e Almeida et al., 2020), lower cardiovascular and respiratory mortality risk (Donovan et al., 2013; Blount et al., 2020), and the reduction of preventable premature deaths (Kondo et al., 2020).

However, trees in urban green spaces may also produce and emit allergenic pollen (Thompson \& Thompson, 2003; Cariñanos \& Casares-Porcel, 2011; Cheng \& Berry, 2013; Cariñanos et al., 2017; Kasprzyk, Cwik, Kluska, Wojcik, \& Cariñanos, 2019; Lara, Rojo, Fernández-González, \& Pérez-Badia, 2019; Cariñanos, Ruiz-Peñuela, Valle, \& de la Guardia, 2020). An increasing number of studies has found that allergenic pollen, in combination with air pollution and other agents such as fungal spores, may initiate airway inflammation, trigger allergic respiratory disease, and increase susceptibility to respiratory viral infections (Dadvand et al., 2014; Lambert et al., 2017; Eisenman, Jariwala, \& Lovasi, 2019; Lai \& Kontokosta, 2019; Gilles et al., 2020; Lambert et al., 2020; Lee et al., 2020). The health risks 
associated with tree pollen are therefore important public health aspects of urban green spaces (van Dorn, 2017; Eisenman et al., 2019; Jia, Wang, van Vliet, Skidmore, \& van Aalst, 2020; Sousa-Silva, Smargiassi, Paquette, Kaiser, \& Kneeshaw, 2020).

The allergy risks posed by trees in urban green spaces are primarily determined by the tree species composition (allergenic vs. non-allergenic tree species) and the abundance of trees (the number of trees). The allergenicity of individual trees depends on their dimensions (in particular crown volume, which depends on tree height, crown diameter and crown shape) and on a number of specific traits of the tree species: the pollen allergen potency (the amount of allergens measured as mass per pollen grain), the pollen dispersal syndrome (higher risks in wind-dispersed species), and the pollen season duration (Cariñanos, Casares-Porcel, \& Quesada-Rubio, 2014). The allergenicity of individual tree species may vary across regions as there are regional differences in pollen allergen sensitization (Röseler et al., 2020). For example, planes (Platanus spp.), olive (Olea europaea), and some maples (Acer spp.) may be highly allergenic throughout their native distributional range but only mildly allergenic (at the population level) in their introduced range. Non-indigenous allergenic plants usually have less impact on allergies than indigenous allergenic plants because they are generally found in lower abundance and produce allergens for which the general population is not yet sensitized. However, in some cases, introduced species may become important allergenic plants outside of their natural ranges, especially when these species are cultivated or when they have become naturalized, occur in large quantities and are present in or near densely populated areas (e.g. Cupressus arizonica in Spain or Ambrosia artemisiifolia in Central Europe) (Rojo, Rapp, Lara, Sabariego, Fernández-González, \& Pérez-Badia, 2016; Lake et al.,2017). In urban green spaces in NW Europe, three indigenous taxa, i.e. birch (Betula spp.), alder (Alnus spp.) and hazel (Corylus spp.), are the most important sources of allergenic tree pollen (Damialis, Traidl-Hoffmann, \& Treudler, 2019). 
There are a number of global environmental challenges which are expected to increase the amount and the allergen potency of airborne allergenic pollen, resulting in higher allergy risks (Damialis et al., 2019; D’Amato, Cecchi, Annesi-Maesano, \& D’Amato, 2018). Higher temperatures under the influence of climate change and the urban heat island effect, combined with traffic-related air pollution (ozone $\left[\mathrm{O}_{3}\right]$ and nitrogen dioxide $\left[\mathrm{NO}_{2}\right]$ ), elevated carbon dioxide $\left(\mathrm{CO}_{2}\right)$ concentrations and nutrient deposition (e.g. nitrogen), may contribute to increases in length and intensity of pollination seasons (Reed \& Gamble, 2009; D’Amato, Vitale, Lanza, Molino, \& D’Amato, 2016). Several studies have already reported an earlier onset of the pollen season for birch, oak (Quercus spp.), ash (Fraxinus spp.) and plane, an increase in daily airborne tree pollen concentrations of alder, hazel, ash and plane, and an increase of the number of days with pollen concentrations exceeding the critical threshold for provoking allergy symptoms in the sensitized population (Zielo et al., 2012; Bruffaerts et al., 2018; Hoebeke et al., 2018; Damialis et al., 2019; Ziska et al., 2019). Increased $\mathrm{CO}_{2}$ concentrations have been associated with higher plant total biomass and pollen production (Ziska et al., 2003), whereas long-term high $\mathrm{O}_{3}$ and $\mathrm{NO}_{2}$ levels in urban environments have been associated with increased allergenicity of pollen of a number of species including birch (Beck et al., 2013; Zhao et al., 2016; Gilles et al., 2018; Plaza, Alcázar, Oteros, \& Galán, 2020). As a result of longer exposure to higher amounts of more potent allergenic pollen, sensitization rates for the major tree pollen allergens have increased, as well as the frequency and severity of pollen-induced allergy, asthma, and respiratory disease (Heinzerling et al., 2009; D’Amato \& Cecchi, 2008; Damialis et al., 2019).

Previous works on urban green space allergy risks have insufficiently addressed the potential impacts of environmental change. A better understanding of the existing and potential future allergy risks posed by urban green spaces may guide urban planning decisions (van Dorn, 2017), inform urban green space management (Cariñanos \& Casares- 
Porcel, 2011), and help pollen allergy patients to avoid environmental triggers during the airborne pollen season (D'Amato et al., 2020). The aim of our study was therefore to examine tree pollen allergy risks in urban green spaces in the Brussels Capital Region, Belgium, and changes in allergy risks associated with green space interventions, potential changes in tree allergenic potential and increased pollination duration.

\section{Methods}

\subsection{Study sites and tree data}

We used tree inventory datasets of 18 urban green spaces in the Brussels Capital Region, Belgium (Table S1, Fig. 1). The datasets contained records for all trees present in the 18 green spaces ( $n=5940$ trees). For each tree, we extracted the following data: $\mathrm{X}$ and Y coordinates of the tree, species name, circumference at $1.5 \mathrm{~m}$ height $(\mathrm{cm})$, tree height class $(2-5 \mathrm{~m}, 5-10$ $\mathrm{m}, 10-15 \mathrm{~m}, 15-20 \mathrm{~m}, 20-25 \mathrm{~m}, 25-30 \mathrm{~m})$, and crown diameter class (1-5 m, 5-10 m, 10-15 $\mathrm{m}, 15-20 \mathrm{~m}, 20-25 \mathrm{~m}, 25-30 \mathrm{~m})$. The extent of each green space was determined in Google Earth, using the tree location data as reference. Green space surface areas were measured (ha) and these values included, when present, impervious surfaces and water bodies located within the urban green space. The surface areas and numbers of trees recorded in the green spaces included in this study are listed in Table S1.

\subsection{Tree pollen allergy risk}

The present tree pollen allergy risk of urban green spaces was determined using the urban green zone allergenicity index $\left(I_{U G Z A}\right)$ method, which was proposed by Cariñanos, Casares-Porcel, \& Quesada-Rubio (2014). It takes into account tree dimensions and the allergenic potential, pollination syndrome, and pollen season duration of different tree species. Here we extended the $I_{U G Z A}$ method to assess changes in tree pollen allergy risk associated with aspects of 
environmental change. The formula to calculate $I_{U G Z A}$ was modified in such a way that the index could be calculated using the data from individual trees contained in our tree inventory datasets:

$$
I_{U G Z A}=\frac{1}{a \times S_{T}} \sum_{i=1}^{n} A P_{i} \times P S_{i} \times P S D_{i} \times S_{i} \times H_{i}
$$

where $n=$ the number of trees, $A P_{i}=$ the allergenic potential of tree $i(0:$ non-allergenic, $1:$ low allergenicity, 2: moderate allergenicity, 3: high allergenicity, or 4: main local allergen, in this study $A P_{i}=4$ for Betula pendula, Alnus glutinosa, Alnus incana, and Corylus avellana; D'Amato et al., 2007; Damialis et al., 2019), $P S_{i}=$ the pollination syndrome of tree $i$ (0: no pollen dispersal (only female individuals), 1: entomophilous (insect-pollinated), 2: amphiphilous (insect- or wind-pollinated), 3: anemophilous (wind-pollinated)), $P S D_{i}=$ the pollen season duration of tree $i$ (1:1-3 weeks, 2: 4-6 weeks, 3: more than 6 weeks), $S_{i}=$ the vertical crown projection area of tree $i\left(\mathrm{~m}^{2}\right)$ calculated from the crown diameter $D_{i}$ as $S_{i}=\pi \times$ $\left(D_{i} / 2\right)^{2}, H_{i}=$ the height of tree $i(\mathrm{~m}), S_{T}=$ the total surface area of the urban green space $\left(\mathrm{m}^{2}\right)$, and $a=$ a scale variable that sets the range of $I_{U G Z A}$ so that $I_{U G Z A}=0$ for non-allergenic urban green spaces and $I_{U G Z A}=1$ for urban green spaces with maximum tree pollen allergy risk. The scale variable depends on the maxima of four variables: $a=A P_{\text {imax }} \times P S_{\text {imax }} \times P S D_{\text {imax }} \times H_{\text {imax }}$ $=4 \times 3 \times 3 \times 30=1080$ [note that we have used a maximum tree height of $30 \mathrm{~m}$, which is larger than the maximum tree height used in Cariñanos, Casares-Porcel, \& Quesada-Rubio (2014) (14 m) but which is better adapted to the local growing conditions]. A hypothetical homogeneous, even-aged birch forest with $100 \%$ crown cover and canopy height of $30 \mathrm{~m}$ maximally fills the hypothetical green space with the most allergenic tree species (in this region) and would obtain $I_{U G Z A}=1$. $I_{U G Z A}$ can thus be interpreted as the relative tree pollen allergy risk compared to the reference urban green space with the highest tree pollen allergy risk, i.e. homogeneous birch forest (Fig. S1). The values of the allergenic potential, pollination 
syndrome and pollen season duration of the allergenic tree species $\left(A P_{i}>0\right)$ that were used in this study were adapted from Cariñanos, Casares-Porcel, \& Quesada-Rubio (2014) based on the airborne pollen observations of the Belgian Aerobiological Surveillance Network and are listed in Table S2.

Because tree height and crown diameter were ordinal (class) data, we used a randomization function to assign random integer values between the lower and upper limits of the classes as estimates for tree height $H_{i}$ and crown diameter $D_{i}$. We calculated multiple values of $I_{U G Z A}$ for each urban green space, in which new random integer numbers for $H_{i}$ and $D_{i}$ were generated for each tree for every calculation of $I_{U G Z A}(k=20$ iterations for every green space $\times$ scenario combination). The standard deviations associated with average $I_{U G Z A}$ values consequently reflect uncertainty in the tree dimension data.

\subsection{Change scenarios}

First, the tree pollen allergy risk of each urban green space was calculated for the present situation (baseline $\left.I_{U G Z A}\right)$. Then $I_{U G Z A}$ was calculated repeatedly for 13 scenarios that represented potential changes in tree species composition, allergenic potential, and pollen season duration, respectively by removing trees from the inventory, by adjusting $A P_{i}$ values, or by adjusting $P S D_{i}$ values (Table 1). Changes in allergenic potential could be due to increased pollen allergen potency, increased sensitization of the population, or increased cross-reactivity between pollen of different tree species (e.g. between birch pollen and pollen of oak, beech [Fagus sylvatica], chestnut [Castanea sativa] and hornbeam [Carpinus betulus]).

The main scenarios were: TR1, removal of all ash trees following ash dieback [an ongoing destructive fungal disease caused by the ascomycete fungus Hymenoscyphus fraxineus (syn. Chalara fraxinea) and which may temporarily intensify ash pollen emissions (Gassner, Schmid-Grendelmeier, \& Clot, 2019)]; TR2, preventive removal of all birch, alder, 
and hazel trees to reduce allergy risk; TR3, removal of all horse chestnut trees following horse chestnut dieback (an ongoing disease primarily caused by the bacterium Pseudomonas syringae pv. aesculi); IP1, increased allergenic potential of birch, alder, and hazel; IP2, increased allergenic potential of plane; IP3, increased allergenic potential of ash; IP4, increased allergenic potential of oak, beech, chestnut and hornbeam; IPD, increased pollination duration; CS1, increased pollination duration + increased allergenic potential of ash and plane (scenarios IP2 + IP3 + IPD); CS2, increased pollination duration + increased allergenic potential of ash, plane, oak, beech, chestnut, and hornbeam (scenarios IP2 + IP3 + IP4 + IPD); and CS3, increased pollination duration + increased allergenic potential of ash, plane, oak, beech, chestnut, hornbeam, birch, alder, and hazel (scenarios IP1 + IP2 + IP3 + IP4 + IPD).

We then combined the preventive tree removal scenario TR2 with two combined scenarios $(\mathrm{CS} 1, \mathrm{CS} 2)$ to determine whether preventive removal of the main allergenic tree species could sufficiently counter increases in AR caused by other species (CS4: scenarios IP2 + IP3 + IPD + TR2; CS5: scenarios IP2 + IP3 + IP4 + IPD + TR2). We did not combine CS3 with TR2 as removal of birch, alder, and hazel trees cancels out the effect of increased allergenic potential of these species.

\subsection{Statistical analysis}

Because the magnitude of changes in tree pollen allergy risks depends on the initial risk, urban green spaces were first stratified in two groups: green spaces with 'low' vs. 'high' initial tree pollen allergy risk (i.e. average baseline $I_{U G Z A}$ below vs. above the overall median). Change scenarios within these two groups were then evaluated using linear mixed models. We used scenario as the fixed effect and green space ID as subject variable. We included a random intercept to account for the multiple estimations of $I_{U G Z A}$ per scenario per 
urban green space. We calculated estimated marginal means for all scenarios. We present the mean difference in tree pollen allergy risk between scenario and baseline $\left(\Delta I_{U G Z A}\right)$ and the 95\% confidence intervals (CI) of this difference and the associated $p$ values as the scenario effects. Statistical analyses were performed with IBM SPSS Statistics Subscription 11-2018 software.

\section{Results}

\subsection{Green space characteristics}

The most abundant tree species were Acer pseudoplatanus $(n=793$ individual trees; $13 \%$ of the trees included in the dataset) and Taxus baccata $(n=612 ; 10 \%)$, which are considered to play no role in pollinosis in Belgium at the population level. The most abundant allergenic tree species was Fraxinus excelsior $(n=466 ; 8 \%)$. The most frequent tree species were Acer platanoides (present in 17 of 18 green spaces), F. excelsior (17) and Carpinus betulus (16) (Table 2). The main allergenic tree species, Corylus avellana, Alnus glutinosa and Betula pendula, were present in respectively 6,8 and 11 green spaces but were much less abundant (only $1.3,1.3$ and $0.2 \%$ of all included trees, respectively). Other characteristics of the green spaces are presented in Table S1.

\subsection{Baseline allergy risk}

The overall average baseline allergy risk across all green spaces was 0.079 (SD 0.047; range $0.002-0.18 ; 95 \%$ CI $0.074-0.084$ ); the median baseline allergy risk was 0.081 (interquartile range $\mathrm{IQR}=0.053)$. In the subset of green spaces with low baseline allergy risk $\left(I_{U G Z A}<\right.$ median), the average baseline allergy risk was 0.043 (95\% CI 0.015-0.071), compared to $0.114(95 \%$ CI $0.089-0.140)$ in the subset of green spaces with high baseline allergy risk $\left(I_{U G Z A}>\right.$ median) (Fig. 2; Table S3). 


\subsection{Changes of allergy risk across scenarios}

The changes of allergy risks across scenarios are summarized in Fig. 3, Table S3, and Table S4. In the scenarios for increased allergenic potential (IP2, IP3, IP4), $\Delta I_{U G Z A}$ was 0.006 (95\% CI $0.003 ; 0.009)$ for Platanus $(+14 \%, p<0.001), 0.003$ (95\% CI 0.000; 0.006) for Fraxinus $(+7 \%, p=0.042)$, and $0.013(95 \%$ CI $0.011 ; 0.016)$ for the group Quercus, Fagus, Castanea, and Carpinus $(+30 \%, p<0.001)$ in the green spaces with low baseline allergy risk. In the green spaces with high baseline allergy risk, $\Delta I_{U G Z A}$ was $0.014(95 \% \mathrm{CI} 0.011 ; 0.018)$ for Platanus (+12\%), $0.017(0.013 ; 0.020)$ for Fraxinus $(+15 \%)$ and $0.030(0.026 ; 0.033)$ for the group Quercus, Fagus, Castanea, and Carpinus (+26\%) (all $p<0.001)$. The scenario for increased allergenic potential of birch, hazel and alder (IP1) had no significant effect on tree pollen allergy risk $\left(\Delta I_{U G Z A}=0.001,95 \% \mathrm{CI}-0.002 ; 0.004, p=0.657\right.$ and $\Delta I_{U G Z A}=0.000$, $95 \% \mathrm{CI}-0.003 ; 0.004, p=0.917$ for green spaces with low and high baseline allergy risk, respectively) because the allergenic potential was already maximal $\left(A P_{i}=4\right)$ for the main allergenic species.

In the scenario for increased pollination duration (IPD), $\Delta I_{U G Z A}$ was $0.019(0.016$; $0.022)$ in the green spaces with low baseline allergy risk $(+44 \%)$ and $0.052(0.048 ; 0.055)$ in the green spaces with high baseline allergy risk $(+46 \%)($ all $p<0.001)$.

In the scenarios of combined increased allergenic potential and increased pollination duration (CS1, CS2, CS3), $\triangle I_{U G Z A}$ was $0.033(0.030 ; 0.036), 0.048(0.045 ; 0.051)$, and 0.049 $(0.046 ; 0.052)$ in the green spaces with low baseline allergy risk $(+76 \%,+112 \%$, and $+114 \%)$ and $0.097(0.096 ; 0.101)$ for CS1 and $0.134(0.130 ; 0.137)$ for CS2 and CS3 in the green spaces with high baseline allergy risk $(+85 \%$ and $+118 \%)($ all $p<0.001)$.

In the scenarios that simulated dieback of Fraxinus (TR1), preventive removal of Betulaceae (TR2), and dieback of Aesculus (TR3), $\Delta I_{U G Z A}$ was $-0.006(-0.009 ;-0.003)$ for TR1 and TR2 (both $p<0.001)$ and $-0.005(-0.008 ;-0.002)$ for TR3 $(p=0.002)$ in the green 
spaces with low baseline allergy risk $(-14 \%$ and $-12 \%)$ and $-0.032(-0.036 ;-0.028),-0.015$ $(-0.019 ;-0.011)$, and $-0.009(-0.012 ;-0.005)$ in the green spaces with high baseline allergy risk $(-28 \%,-13 \%$, and $-8 \%)($ all $p<0.001)$.

In the scenarios that combined the preventive tree removal scenario with the two combined scenarios (CS4, CS5), $\Delta I_{U G Z A}$ was $0.026(0.023 ; 0.029)$ and $0.042(0.039 ; 0.045)$ in the green spaces with low baseline allergy risk $(+61 \%,+98 \%)$ and $0.079(0.075 ; 0.083)$ and $0.117(0.113 ; 0.121)$ in the green spaces with high baseline allergy risk $(+69 \%,+103 \%)($ all $p$ $<0.001)$.

\section{Discussion}

\subsection{Main findings}

We investigated tree pollen allergy risks in urban green spaces in the Brussels Capital Region in Belgium. The allergy risk due to exposure to locally emitted pollen is at present low, in part because of the limited presence of the main allergenic tree genera Corylus, Alnus and Betula. However, several tree species with low to moderate allergenicity, in particular Fraxinus excelsior, occur in a large proportion of the studied green spaces and in relatively high quantities. Therefore, tree pollen allergy risks could considerably rise when ongoing environmental changes lead to a combination of longer pollen seasons, increased pollen allergen potency, and increased sensitization for one or more species. In our estimates for such combined scenarios, the allergy risk doubles in all green spaces, irrespective of low or high baseline allergy risk. The preventive removal of the main allergenic tree species cannot sufficiently counter increases in allergy risks caused by other species. 


\subsection{Comparison with other studies}

The allergenicity index $I_{U G Z A}$ was used earlier to assess the allergy risks of urban green spaces, with the majority of studies carried out in Mediterranean cities. In the original study that described the allergenicity index, one green space located in Granada (Spain) had a $I_{U G Z A}$ $=0.14$ (Cariñanos, Casares-Porcel, \& Quesada-Rubio, 2014). In a study of the 8 most important urban green areas in the city of Córdoba (Spain), the $I_{U G Z A}$ ranged between 0.04 and 0.60, with an average of 0.25 (95\% CI 0.06-0.43) (Velasco-Jiménez, Alcázar, Cariñanos, \& Galán, 2020). In a study of 26 urban green spaces in 24 Spanish cities, the $I_{U G Z A}$ ranged between 0.07 and 0.87, with an average of 0.34 (95\% CI 0.25-0.43) (Cariñanos et al., 2017). In a broader study of 34 urban green spaces located in 23 cities in six Mediterranean countries (France, Italy, Morocco, Portugal, Spain, and Slovenia), the $I_{U G Z A}$ ranged between 0.03 and 1.00, with an average of 0.27 (95\% CI 0.18-0.37) (Cariñanos et al., 2019). One study of three green spaces in Rzeszów (South-Eastern Poland) reported an average $I_{U G Z A}$ of 0.26 (SD 0.06) (Kasprzyk, Cwik, Kluska, Wojcik, \& Cariñanos, 2019) and another study of one green space located in Eichstätt (Germany) reported an $I_{U G Z A}=0.17$ (Jochner-Oette, Stitz, Jetschni, \& Cariñanos, 2018).

The $I_{U G Z A}$ values recorded in the urban green spaces of the Brussels Capital Region were on average much lower than those recorded in the Mediterranean cities and elsewhere, and could in most cases considered to be low (Fig. 2, Table S3). Compared to the Mediterranean green spaces, Platanus was much less frequent and abundant in Brussels, leading to lower $I_{U G Z A}$ values. In the Mediterranean cities more taxa contributed to the allergenicity index . Some taxa with high allergenicity in the Mediterranean green spaces such as Australian pine (Casuarina equisetifolia) and Tuscany cypress (Cupressus sempervirens) were not present in our sample. Two other species, paper mulberry (Broussonetia papyrifera) and mulberry (Morus spp.), were present in the studied green 
spaces in Brussels but there were only a few individuals. Both species are not considered to play a role in pollinosis in the region (yet) $(A P=0)$, although they have pollen that has been linked to allergic reactions elsewhere (Zanforlin \& Incorvaia, 2004; Wu, Su, Lung, Chen, \& Lin, 2019; Qazi, Iqbal, \& Khan, 2019; Papia, Incorvaia, Genovese, Gangemi, \& Minciullo, 2020). Also, we focused on allergy risks associated with tree pollen and have not included grasses or herbaceous vegetation in our assessment. Including grass in our calculation of allergy risks could considerably increase the values of $I_{U G Z A}$.

\subsection{Implication for management}

The allergy risks increased by $11-27 \%$ in increased allergenic potential scenarios, and by $44 \%$ in the increased pollen season duration scenario. Preventive removal of birch, hazel and alder reduced the AR by $13 \%$. The AR increased by $99-111 \%$ in combined scenarios with and without preventive removal of the main allergenic taxa. The increased pollen season duration was therefore the main driver of increased allergy risks. The length of the pollen season nor the allergenic potential of tree species can be influenced by green space management. Therefore, removing allergenic tree species and replacement by non-allergenic taxa seems to be the only method to efficiently counter increasing tree pollen allergy risks. Indeed, Mrdan, Ljubojevic, Orlovic, Cukanovic, \& Dulic (2017) suggested to remove birch and other allergenic tree species from school yards to reduce childhood allergy risks. MayaManzano et al. (2017) proposed to reduce the number of trees with wind-dispersed pollen and to eliminate male (pollen-producing) trees to decrease the amount of allergenic pollen in the air. However, the removal of the main allergenic genera Corylus, Alnus and Betula (TR2) resulted only in a limited reduction of the allergy risks because these taxa are present but not numerous in the studied green spaces. Therefore, the marginal reduction of the allergy risk probably does not justify the potential biodiversity losses that would be caused by removing 
these tree species. Similarly, increased sensitization to Platanus pollen amplified green space allergenic potential, but only by $12 \%$. Because the ecosystem services of Platanus, in particular providing shade and mitigating urban heat, may outweigh the potential increases in pollen allergy burden, and because the removal of large old trees is usually not appreciated by the public, removing Platanus trees is - at present - not recommended either. We propose that management options that aim to mitigate the impact of allergens on the health of the population and that include tree removal, should always be screened for their effectiveness by calculating allergy risk changes across different scenarios. For the design of new green spaces, allergenicity of tree species should be taken into account (Vogt et al., 2017; Lara et al., 2020).

\subsection{Limitations}

Our research may have a number of limitations. First, the allergenicity index does not take into account the inter-annual variability of pollen season intensities and can therefore not be used to compare the allergy risks between low seed years and mast seeding years. Second, the allergenicity index does not take into account variability in the pollen production capacity. At very local and even individual tree scale, tree phenology can be influenced by many environmental factors including intra-urban temperature variation (Katz, Dzul, Kendel, \& Batterman, 2019). Therefore, green spaces with exactly the same allergenicity index might present different AR because of locally modified pollen production intensity and duration. Third, the allergenicity index as used in this study focusses on tree pollen, and therefore does not take into account allergy risks associated with grass pollen and allergenic herbs such as mugwort (Artemisia vulgaris) and novel pollen allergens such as the invasive alien ragweed (Ambrosia artemisiifolia) and Bermuda grass (Cynodon dactylon) (Röseler et al., 2020). Grass pollen is the leading aeroallergen in world (García-Mozo, 2017) and ragweed may become a 
major source of allergens throughout Europe (Lake et al., 2017). However, lawns probably contribute little to the overall allergy risk of urban green spaces as frequent mowing limits flowering and hence pollen emissions. Fourth, the allergenicity index does not take into account pollen released by vegetation in the surrounding landscape, such as street trees, gardens, road verges or other urban green spaces, nor does it account for long range transport of allergenic pollen. Finally, it is difficult to translate tree pollen allergy risk of urban green spaces to risks at the level of the individual, as exposure to a single allergenic tree in full bloom may provoke strong allergic reactions in sensitized individuals even if the green space has an overall low allergy risk.

\section{Conclusion}

In conclusion, we estimated that the tree pollen allergy burden of urban green spaces could considerably increase under the influence of global environmental changes that lead to longer pollen season duration, increased pollen allergen potency, and higher sensitization of the population. Allergenic tree diseases and preventive removal of the main allergenic trees may only partially mitigate allergy risks that are amplified by environmental change. While it may be worth to invest in the establishment of new hypoallergenic green spaces in and near cities, the removal of allergenic tree taxa such as Betula and Platanus from existing green spaces is not recommended in the light of the conservation of biodiversity and important ecosystem services. These results highlight the importance of careful tree species selection in future urban green space policy and planning. 


\section{References}

Aerts R, Stas M, Vanlessen N, Hendrickx M, Bruffaerts N, Hoebeke L, et al., 2020. Residential green space and seasonal distress in a cohort of tree pollen allergy patients. Int $\mathrm{J}$ Hyg Environ Health 223:71-79, https://doi.org/10.1016/j.ijheh.2019.10.004

Astell-Burt T, Feng X. 2019. Urban green space, tree canopy and prevention of cardiometabolic diseases: a multilevel longitudinal study of 46786 Australians. Int J Epidemiol, dyz239, https://doi.org/10.1093/ije/dyz239

Beck I, Jochner S, Gilles S, McIntyre M, Buters JTM, Schmidt-Weber C, Behrendt H, Ring J, Menzel A, Traidl-Hoffmann C. 2013. High environmental ozone levels lead to enhanced allergenicity of birch pollen. PLoS ONE 8:e80147, https://doi.org/10.1371/journal.pone.0080147

Blount RJ, Pascopella L, Barry P, Zabner J, Stapleton EM, Flood J, Balmes J, Nahid P, Catanzaro DG. 2020. Residential urban tree canopy is associated with decreased mortality during tuberculosis treatment in California. Sci Total Environ 711:134580, https://doi.org/10.1016/j.scitotenv.2019.134580

Bruffaerts N, De Smedt T, Delcloo A, Simons K, Hoebeke L, Verstraeten C, Van Nieuwenhuyse A, Packeu A, Hendrickx M. 2018. Comparative long-term trend analysis of daily weather conditions with daily pollen concentrations in Brussels, Belgium. Int $\mathbf{J}$ Biometeorol 62:483-491, https://doi.org/10.1007/s00484-017-1457-3

Cariñanos P, Casares-Porcel M, Díaz de la Guardia C, Aira MJ, Belmonte J, Boi M, et al., 2017. Assessing allergenicity in urban parks: a nature-based solution to reduce the impact on public health. Environ Res 155:219-227, https://doi.org/10.1016/j.envres.2017.02.015

Cariñanos P, Casares-Porcel M, Quesada-Rubio JM. 2014. Estimating the allergenic potential of urban green spaces: A case-study in Granada, Spain. Landscape Urban Plan 123:134144, https://doi.org/10.1016/j.landurbplan.2013.12.009 
Cariñanos P, Casares-Porcel M. 2011. Urban green zones and related pollen allergy : A review. Some guidelines for designing spaces with low allergy impact. Landscape Urban Plan 101:205-214, https://doi.org/10.1016/j.landurbplan.2011.03.006

Cariñanos P, Grilo F, Pinho P, Casares-Porcel M, Branquinho C, Acil N, et al.,2019. Estimation of the allergenic potential of urban trees and urban parks: towards the healthy design of urban green spaces of the future. Int $\mathbf{J}$ Environ Res Public Health 16:1357, https://doi.org/10.3390/ijerph16081357

Cariñanos P, Ruiz-Peñuela S, Valle AM, de la Guardia CD. 2020. Assessing pollination disservices of urban street-trees: The case of London-plane tree (Platanus $x$ hispanica Mill. $\begin{array}{lllll}\text { ex } & \text { Münchh). } & \text { Sci } & \text { Total }\end{array}$ https://doi.org/10.1016/j.scitotenv.2020.139722

Cheng JJ, Berry P. 2013. Health co-benefits and risks of public health adaptation strategies to climate change: a review of current literature. Int J Public Health 58:305-311, https://doi.org/10.1007/s00038-012-0422-5

Collins RM, Spake R, Brown KA, Ogutu BO, Smith D, Eigenbrod F. 2020. A systematic map of research exploring the effect of greenspace on mental health. Landscape Urban Plan 201:103823, https://doi.org/10.1016/j.landurbplan.2020.103823

D’Amato M, Cecchi L, Annesi-Maesano I, D’Amato G. 2018. News on climate change, air pollution, and allergic triggers of asthma. J Investig Allergol Clin Immunol 28:91-97, https://doi.org/10.18176/jiaci.0228

D’Amato G, Cecchi L, Bonini S, Nunes C, Annesi-Maesano I, Behrendt H, Liccardi G, Popov T, van Cauwenberge P. 2007. Allergenic pollen and pollen allergy in Europe. Allergy 62:976-990, https://doi.org/10.1111/j.1398-9995.2007.01393.x 
D'Amato G, Cecchi L. 2008. Effects of climate change on environmental factors in respiratory allergic diseases. Clinical Experim Allergy 38:1264-1274, https://doi.org/10.1111/j.13652222.2008.03033.x

D’Amato G, Ortega OPL, Annesi-Maesano I, D’Amato M. 2020. Prevention of allergic asthma with allergen avoidance measures and the role of exposome. Curr Allergy Asthma Rep 20:8, https://doi.org/10.1007/s11882-020-0901-3

D’Amato G, Vitale C, Lanza M, Molino A, D’Amato M. 2016. Climate change, air pollution, and allergic respiratory diseases: an update. Curr Opin Allergy Clin Immunol 16:434-440, https://doi.org/10.1097/aci.0000000000000301

Dadvand P, Villanueva CM, Font-Ribera L, Martinez D, Basagaña X, Belmonte J, Vrijheid M, Gražulevičienė R, Kogevinas M, Nieuwenhuijsen MJ. 2014. Risks and benefits of green spaces for children: a cross-sectional study of associations with sedentary behavior, obesity, asthma, and allergy. Environ Health Perspect 122:1329-1335, https://doi.org/10.1289/ehp.1308038

Damialis A, Traidl-Hoffmann C, Treudler R. 2019. Climate change and pollen allergies. Pages 47-66 in: Marselle MR, Stadler J, Korn H, Irvine KN, Bonn A. (Eds.) Biodiversity and Health in the Face of Climate Change, SpringerOpen, Cham, https://doi.org/10.1007/978$\underline{3-030-02318-8 \_3}$

de Oliveira e Almeida L, Favaro A, Raimundo-Costa W, Borella AC, Anhê M, Ferreira DC, Blanes-Vidal V, Dos Santos Senhuk APM. 2020. Influence of urban forest on traffic air pollution and children respiratory health. Environ Monit Assess 192:175, https://doi.org/10.1007/s10661-020-8142-4

Donovan GH, Butry DT, Michael YL, Prestemon JP, Liebhold AM, Gatziolis D, Mao MY. 2013. The relationship between trees and human health: evidence from the spread of the 
emerald ash borer. Am J Prev Med. 2013;44:139-145, https://doi.org/10.1016/j.amepre.2012.09.066

Eisenman TS, Churkina G, Jariwala SP, Kumar P, Lovasi GS, Pataki DE, Weinberger KR, Whitlow TH. 2019. Urban trees, air quality, and asthma: An interdisciplinary review. Landscape Urban Plan 187:47-59, https://doi.org/10.1016/j.landurbplan.2019.02.010

Eisenman TS, Jariwala SP, Lovasi GS. 2019. Urban trees and asthma: a call for epidemiological research. Lancet Respir Med 7:e19-e20, https://doi.org/10.1016/S2213$\underline{2600(19) 30193-6}$

Gassner M, Schmid-Grendelmeier P, Clot B. 2019. Ash pollen allergy and aerobiology. Allergo J Int 28:289-298, https://doi.org/10.1007/s40629-019-00105-6

García-Mozo H. 2017. Poaceae pollen as the leading aeroallergen worldwide: a review. Allergy 72:1849-1858, https://doi.org/10.1111/all.13210

Gernes R, Brokamp C, Rice GE, Wright JM, Kondo MC, Michael YL, et al.,2019. Using highresolution residential greenspace measures in an urban environment to assess risks of allergy $\begin{array}{lllll}\text { outcomes } & \text { in } & \text { children. } & \text { Sci }\end{array}$ https://doi.org/10.1016/j.scitotenv.2019.03.009

Gilles S, Akdis C, Lauener R, Schmid-Grendelmeier P, Bieber T, Schäppi G, Traidl-Hoffmann C. 2018. The role of environmental factors in allergy: A critical reappraisal. Exp Dermatol 27:1193-1200, https://doi.org/10.1111/exd.13769

Gilles S, Blume C, Wimmer M, Damialis A, Meulenbroek L, Gökkaya M, Bergougnan C, Eisenbart S, Sundell N, Lindh M, Andersson LM, Dahl Å, Chaker A, Kolek F, Wagner S, Neumann AU, Akdis CA, Garssen J, Westin J, van't Land B, Davies DE, Traidl-Hoffmann C. 2020. Pollen exposure weakens innate defense against respiratory viruses. Allergy 75:576-587, https://doi.org/10.1111/all.14047 
Heinzerling LM, Burbach GJ, Edenharter G, Bachert C, Bindslev-Jensen C, Bonini S, et al., 2009. GA²LEN skin test study I: GA²LEN harmonization of skin prick testing: novel sensitization patterns for inhalant allergens in Europe. Allergy 64:1498-1506, https://doi.org/10.1111/j.398-9995.2009.02093.x

Hoebeke L, Bruffaerts N, Verstraeten C, Delcloo A, De Smedt T, Packeu A, Detandt M, Hendrickx M. 2018. Thirty-four years of pollen monitoring: an evaluation of the temporal variation of pollen seasons in Belgium. Aerobiologia 34:139-155, https://dx.doi.org/10.1007/s10453-017-9503-5

James P, Banay RF, Hart JE, Laden F. 2015. A review of the health benefits of greenness. Curr Epidemiol Rep 2:131-142, https://doi.org/10.1007/s40471-015-0043-7

Jia P, Wang T, van Vliet AJH, Skidmore AK, van Aalst M. 2020. Worsening of tree-related public health issues under climate change. Nature Plants 6:48, https://doi.org/10.1038/s41477-020-0598-2

Jochner-Oette S, Stitz T, Jetschni J, Cariñanos P. 2018. The influence of individual-specific plant parameters and species composition on the allergenic potential of urban green spaces. Forests 9:284, https://doi.org/10.3390/f9060284

Kasprzyk I, Cwik A, Kluska K, Wojcik T, Cariñanos P. 2019. Allergenic pollen concentrations in the air of urban parks in relation to their vegetation. Urban For Urban Greening 46:126486, https://doi.org/10.1016/j.ufug.2019.126486

Katz DSW, Dzul A, Kendel A, Batterman SA. 2019. Effect of intra-urban temperature variation on tree flowering phenology, airborne pollen, and measurement error in epidemiological studies of allergenic pollen. Sci Total Environ 653:1213-1222, https://doi.org/10.1016/j.scitotenv.2018.11.020

Kondo MC, Mueller N, Locke D, Roman LA, Rojas-Rueda D, Schinasi LH, Gascon M, Nieuwenhuijsen MJ. 2020. Health impact assessment of Philadelphia's 2025 tree canopy 
cover goals. Lancet Planet Health 4:e149-e157, https://doi.org/10.1016/s2542$\underline{5196(20) 30058-9}$

Lai Y, Kontokosta CE. 2019. The impact of urban street tree species on air quality and respiratory illness: A spatial analysis of large-scale, high-resolution urban data. Health Place 56:80-87, https://doi.org/10.1016/j.healthplace.2019.01.016

Lake IR, Jones NR, Agnew M, Goodess CM, Giorgi F, Hamaoui-Laguel L, Semenov MA, Solomon F, Storkey J, Vautard R, Epstein MM.et al., 2017. Climate change and future pollen allergy in Europe. Environ Health Perspect 125:385-391, https://doi.org/10.1289/EHP173

Lambert KA, Bowatte G, Tham R, Lodge C, Prendergast L, Heinrich J, Abramson MJ, Dharmage SC, Erbas B. 2017. Residential greenness and allergic respiratory diseases in children and adolescents - a systematic review and meta-analysis. Environ Res 159:212221, https://doi.org/10.1016/j.envres.2017.08.002

Lambert KA, Katerlaris C, Burton P, Cowie C, Lodge C, Garden FL, Prendergast LA, Toelle BG, Erbas B. 2020. Tree pollen exposure is associated with reduced lung function in children. Clin Exp Allergy, https://doi.org/10.1111/cea.13711

Lara B, Rojo J, Fernández-González F, Pérez-Badia R. 2019. Prediction of airborne pollen concentrations for the plane tree as a tool for evaluating allergy risk in urban green areas. Landscape Urban Plan 189:285-295, https://doi.org/10.1016/j.landurbplan.2019.05.002

Lara B, Rojo J, Fernández-González F, González-García-Saavedra A, Serrano-Bravo MD, Pérez-Badia R. 2020. Impact of plane tree abundance on temporal and spatial variations in pollen concentration. Forests 11:817, https://doi.org/10.3390/f11080817

Lee HY, Wu YH, Kusumaning Asri A, Chen TH, Pan WC, Yu CP, Su HJ, Wu CD. 2020. Linkage between residential green spaces and allergic rhinitis among Asian children (case 
study: $\quad$ Taiwan). $\quad$ Landscape $\quad$ Plan 202:103868, https://doi.org/10.1016/j.landurbplan.2020.103868

Maya-Manzano JM, Tormo Molina R, Fernández Rodríguez S, Silva Palacios I, Gonzalo Garijo Á. 2017. Distribution of ornamental urban trees and their influence on airborne pollen in the SW of Iberian Peninsula. Landscape Urban Plan 157:434-446, https://doi.org/10.1016/j.landurbplan.2016.08.011

Mrdan S, Ljubojevic M, Orlovic S, Cukanovic J, Dulic J. 2017. Poisonous and allergenic plant species in preschool's and primary school's yards in the city of Novi Sad. Urban For Urban Greening 25:112-119, https://doi.org/10.1016/j.ufug.2017.05.007

Rojo J, Rapp A, Lara B, Sabariego S, Fernández-González F, Pérez-Badia R. 2016. Characterisation of the airborne pollen spectrum in Guadalajara (central Spain) and estimation of the potential allergy risk. Environ Monitor Assess 188:130, https://doi.org/10.1007/s10661-016-5129-2

Röseler STM, Baron JM, Höflich C, Merk HF, Bas M, Bier H, Dott W, Fietkau K, Hajdu Z, Kaiser L, Kraus T, LAven G, Moll-Slodowy S, Mücke HG, Straff W, Wurpts G, Yazdi AS, Chaker A, Balakirski G. 2020. "New" inhalant plant allergens. Allergol Select 4:1-10, https://doi.org/10.5414/alx02066e

Roy S, Byrne J, Pickering C. 2012. A systematic quantitative review of urban tree benefits, costs, and assessment methods across cities in different climatic zones. Urban For Urban Greening 11:351-363, https://doi.org/10.1016/j.ufug.2012.06.006

Salmond JA, Tadaki M, Vardoulakis S, Arbuthnott K, Coutts A, Demuzere M, Dirks KN, Heaviside C, Lim s, Macintyre H, McInnes RN, Wheeler BW. 2016. Health and climate related ecosystem services provided by street trees in the urban environment. Environ Health 15S1:36, https://doi.org/10.1186/s12940-016-0103-6 
Sousa-Silva R, Smargiassi A, Paquette A, Kaiser D, Kneeshaw D. 2020. Exactly what do we know about tree pollen allergenicity? Lancet Respir Med 8:e10, https://doi.org/10.1016/S2213-2600(19)30472-2

Thompson JL, Thompson JE. 2003. The urban jungle and allergy. Immunol Allergy Clin North Am 23:371-387, https://doi.org/10.1016/S0889-8561(03)00006-7

van den Bosch M, Sang AO. 2017. Urban natural environments as nature-based solutions for improved public health - a systematic review of reviews. Environ Res 158:373-384, https://doi.org/10.1016/j.envres.2017.05.040

van Dorn A. 2017. Urban planning and respiratory health. Lancet Respir Med 5:781-782, https://doi.org/10.1016/S2213-2600(17)30340-5

Papia F, Incorvaia C, Genovese L, Gangemi S, Minciullo P. 2020. Allergic reactions to genus Morus plants: a review. Clin Mol Allergy 18:1, https://doi.org/10.1186/s12948-020-00116$\underline{7}$

Plaza MP, Alcázar P, Oteros J, Galán C. 2020. Atmospheric pollutants and their association with olive and grass aeroallergen concentrations in Córdoba (Spain). Eviron Sci Pollut Res Int, https://doi.org/10.1007/s11356-020-10422-x

Qazi S, Iqbal J, Khan JK. 2019. Assessment of the health impact of paper mulberry (Broussonetia papyrifera L.), an invasive plant species in Islamabad, Pakistan. Geospat Health 14(2), https://doi.org/10.4081/gh.2019.727

Reed CE, Gamble JL. 2009. Aeroallergens, allergic disease, and climate change: impacts and adaptation. Ecohealth 6:458-470, https://doi.org/10.1007/s10393-009-0261-x

Röseler STM, Baron JM, Höflich C, Merk HF, Bas M, et al. (2020). "New” inhalant plant allergens. ALS, 4(1), 1-10. doi:10.5414/ALX02066E. 
Velasco-Jiménez MJ, Alcázar P, Cariñanos P, Galán C. 2020. Allergenicity of the urban green areas in the city of Córdoba (Spain). Urban For Urban Green 49:126600, https://doi.org/10.1016/j.ufug.2020.126600

Vogt J, Gillner S, Hofmann M, Tharang A, Dettmann S, Gerstenberg T, Schmidt C, Gebauer H, Van de Riet K, Berger U, Roloff A. 2017. Citree: A database supporting tree selection for urban areas in temperate climate. Landscape and Urban Planning 157, 14-25. https://doi.org/10.1016/j.landurbplan.2016.06.005

Wu P-C, Su H-J, Lung S-CL, Chen M-J, Lin W-P. 2019. Pollen of Broussonetia papyrifera: An emerging aeroallergen associated with allergic illness in Taiwan. Sci Total Environ 657: 804-810, https://doi.org/10.1016/j.scitotenv.2018.11.324

Zanforlin M, Incorvaia C. 2004. A case of pollinosis to Broussonetia papyrifera. Allergy 59(10):1136-1137, https://doi.org/10.1111/j.1398-9995.2004.00590.x

Zhao F, Elkelish A, Durner J, Lindermayr C, Barbro Winkler J, Ruëff F, et al.,2016. Common ragweed (Ambrosia artemisiifolia L.): allergenicity and molecular characterization of pollen after plant exposure to elevated $\mathrm{NO}_{2}$. Plant Cell Environ 39:147-164, https://doi.org/10.1111/pce.12601

Zielo C, Sparks TH, Estrella N, Belmonte J, Bergmann KC, Bucher E, et al.,2012. Changes to airborne pollen counts across Europe. PLoS ONE 7:e34076, https://doi.org/10.1371/journal.pone.0034076

Ziska LH, Gebhard DE, Frenz DA, Faulkner S, Singer BD, Straka JG. 2003. Cities as harbingers of climate change: common ragweed, urbanization, and public health. J Allergy Clin Immunol 111:290-295, https://doi.org/10.1067/mai.2003.53

Ziska LH, Makra L, Harry SK, Bruffaerts N, Hendrickx M, Coates F, et al., 2019. Temperaturerelated changes in airborne allergenic pollen abundance and seasonality across the northern 
hemisphere: a retrospective data analysis. Lancet Planet Health 3:e124-e131, https://doi.org/10.1016/S2542-5196(19)30015-4 


\section{List of tables}

Table 1. Methods to calculate tree pollen allergy risks in urban green spaces for scenarios for changes in tree species composition, allergenic potential and pollen season duration

Table 2. Most frequent and most abundant tree species in 18 urban green spaces in the Brussels Capital Region, Belgium

Table S1. Characteristics of 18 urban green spaces in the Brussels Capital Region, Belgium, that were included in the study

Table S2. Allergenic potential, pollination syndrome and pollen season duration of allergenic tree species recorded in 18 urban green spaces in the Brussels Capital Region, Belgium

Table S3. Tree pollen allergy risk in 18 urban green spaces ( $\left.I_{U G Z A}\right)$ in the Brussels Capital Region, Belgium, across green space intervention, allergenic potential and pollination duration change scenarios.

Table S4. Relative change (\%) in tree pollen allergy risk in 18 urban green spaces $\left(I_{U G Z A}\right)$ in the Brussels Capital Region, Belgium, across green space intervention, allergenic potential and pollination duration change scenarios. 
Table 1. Methods to calculate tree pollen allergy risks in urban green spaces for scenarios for changes in tree species composition, allergenic potential and pollen season duration

\begin{tabular}{|c|c|c|}
\hline Scenario & Description & Method \\
\hline baseline & Present-day allergy risk (Fig. S2) & $\begin{array}{l}\text { Calculate } I_{U G Z A} \text { using baseline values } \\
\text { for } A P, P S \text { and } P S D \text { (Table S2) }\end{array}$ \\
\hline TR1 & $\begin{array}{l}\text { Removal of all ash trees following ash } \\
\text { dieback }\end{array}$ & Set $A P=0$ for all Fraxinus trees \\
\hline TR2 & $\begin{array}{l}\text { Preventive removal of birch, alder and } \\
\text { hazel trees to reduce allergy risk }\end{array}$ & $\begin{array}{l}\text { Set } A P=0 \text { for all Betula, Alnus and } \\
\text { Corylus trees }\end{array}$ \\
\hline TR3 & $\begin{array}{l}\text { Removal of all horse chestnut trees } \\
\text { following horse chestnut dieback }\end{array}$ & Set $A P=0$ for all Aesculus trees \\
\hline IP1 & $\begin{array}{l}\text { Increased allergenic potential of birch, } \\
\text { alder, and hazel }\end{array}$ & $\begin{array}{l}\text { Set } A P=4 \text { for all Betula, Alnus and } \\
\text { Corylus trees }\end{array}$ \\
\hline IP2 & Increased allergenic potential of plane & Set $A P=3$ for all Platanus trees \\
\hline IP3 & Increased allergenic potential of ash & Set $A P=3$ for all Fraxinus trees \\
\hline IP4 & $\begin{array}{l}\text { Increased allergenic potential of oak, } \\
\text { beech, chestnut and hornbeam }\end{array}$ & $\begin{array}{l}\text { Set } A P=3 \text { for all Quercus, Fagus, } \\
\text { Castanea, and Carpinus trees }\end{array}$ \\
\hline IPD & $\begin{array}{l}\text { Increased pollination duration (earlier } \\
\text { onset and/or longer duration) }\end{array}$ & $\begin{array}{l}\text { For all trees with } P S D=1 \text { or } P S D=2 \\
\text { set } P S D=P S D+1\end{array}$ \\
\hline CS1 & $\begin{array}{l}\text { Increased pollination duration }+ \\
\text { increased allergenic potential of ash } \\
\text { and plane }\end{array}$ & Methods IP2 + IP3 + IPD \\
\hline $\mathrm{CS} 2$ & $\begin{array}{l}\text { Increased pollination duration }+ \\
\text { increased allergenic potential of ash, } \\
\text { plane, oak, beech, chestnut, and } \\
\text { hornbeam }\end{array}$ & Methods IP2 + IP3 + IP4 + IPD \\
\hline CS3 & $\begin{array}{l}\text { Increased pollination duration }+ \\
\text { increased allergenic potential of ash, } \\
\text { plane, oak, beech, chestnut, hornbeam, } \\
\text { birch, alder, and hazel }\end{array}$ & Methods IP1 + IP2 + IP3 + IP4 + IPD \\
\hline CS4 & $\begin{array}{l}\text { Increased pollination duration }+ \\
\text { increased allergenic potential of ash }\end{array}$ & Methods IP2 + IP3 + IPD + TR2 \\
\hline
\end{tabular}


and plane + Preventive removal of birch, alder and hazel trees to reduce allergy risk

CS5 Increased pollination duration + Methods IP2 + IP3 + IP4 + IPD + TR2 increased allergenic potential of ash, plane, oak, beech, chestnut, and hornbeam + Preventive removal of birch, alder and hazel trees to reduce allergy risk 
Table 2. Most frequent and most abundant tree species in 18 urban green spaces in the Brussels Capital Region, Belgium

\begin{tabular}{|c|c|c|c|c|c|}
\hline Rank & Species & $\begin{array}{l}\mathrm{RF}^{\mathrm{a}} \\
(\%)\end{array}$ & Rank & Species & $\begin{array}{l}\mathrm{RA}^{\mathrm{b}} \\
(\%)\end{array}$ \\
\hline 1 & Acer platanoides & 94 & 1 & Acer pseudoplatanus & 13.4 \\
\hline 1 & *Fraxinus excelsior & 94 & 2 & Taxus baccata & 10.3 \\
\hline 3 & *Carpinus betulus & 89 & 3 & *Fraxinus excelsior & 7.8 \\
\hline 4 & Acer pseudoplatanus & 83 & 4 & Robinia pseudoacacia & 5.3 \\
\hline 5 & *Aesculus hippocastanum & 78 & 5 & Acer platanoides & 4.6 \\
\hline 5 & Taxus baccata & 78 & 6 & Pinus nigra & 4.2 \\
\hline 7 & *Fagus sylvatica & 72 & 7 & *Aesculus hippocastanum & 3.7 \\
\hline 7 & $*$ Platanus $\times$ acerifolia & 72 & 8 & *Salix alba & 3.5 \\
\hline 9 & *Tilia platyphyllos & 67 & 9 & *Populus canadensis & 2.6 \\
\hline 10 & *Betula pendula & 61 & 10 & *Carpinus betulus & 2.5 \\
\hline 10 & *Quercus robur & 61 & 11 & *Fagus sylvatica & 2.3 \\
\hline 10 & *Quercus rubra & 61 & 12 & Ilex aquifolium & 2.1 \\
\hline 10 & Robinia pseudoacacia & 61 & 13 & *Quercus robur & 2.0 \\
\hline 14 & Ilex aquifolium & 56 & 14 & *Tilia platyphyllos & 1.7 \\
\hline 14 & Pinus nigra & 56 & 15 & *Tilia tomentosa & 1.4 \\
\hline
\end{tabular}

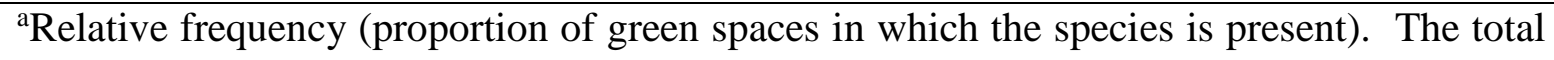
number of green spaces included in this study $=18$

${ }^{b}$ Relative abundance (proportion of trees across all green spaces). The total number of trees included in this study $=5940$

*Allergenic species. For allergenic properties, see Table S2 


\section{List of Figures}

Fig. 1. Green space typology in Brussels Capital Region, Belgium, and location of the 18 urban green spaces that were included in the study, with an indication of their average baseline tree pollen allergy risk $\left(I_{U G Z A}\right)$.

Fig. 2. Tree pollen allergy risk $\left(I_{U G Z A}\right)$ in 18 urban green spaces in the Brussels Capital Region, Belgium. Urban green spaces were stratified in two groups: green spaces with average baseline $I_{U G Z A}$ below vs. above the overall median $\left(\mathrm{P} 50 I_{U G Z A}=0.081\right)$. Shaded intervals indicate the 95\% CIs for $I_{U G Z A}$ subgroup means.

Fig. 3. Changes in tree pollen allergy risk $\left(\triangle I_{U G Z A}\right)$ in urban green spaces in Brussels Capital Region, Belgium, across green space intervention, allergic sensitization and pollination duration change scenarios. Urban green spaces were stratified in two groups: green spaces with average baseline $I_{U G Z A}$ below vs. above the overall median (P50 $\left.I_{U G Z A}=0.081\right) . \Delta I_{U G Z A}$ (average and 95\% CI) is calculated as the estimated difference between the marginal mean $I_{U G Z A}$ of the scenario and the subgroup mean baseline $I_{U G Z A}$. 


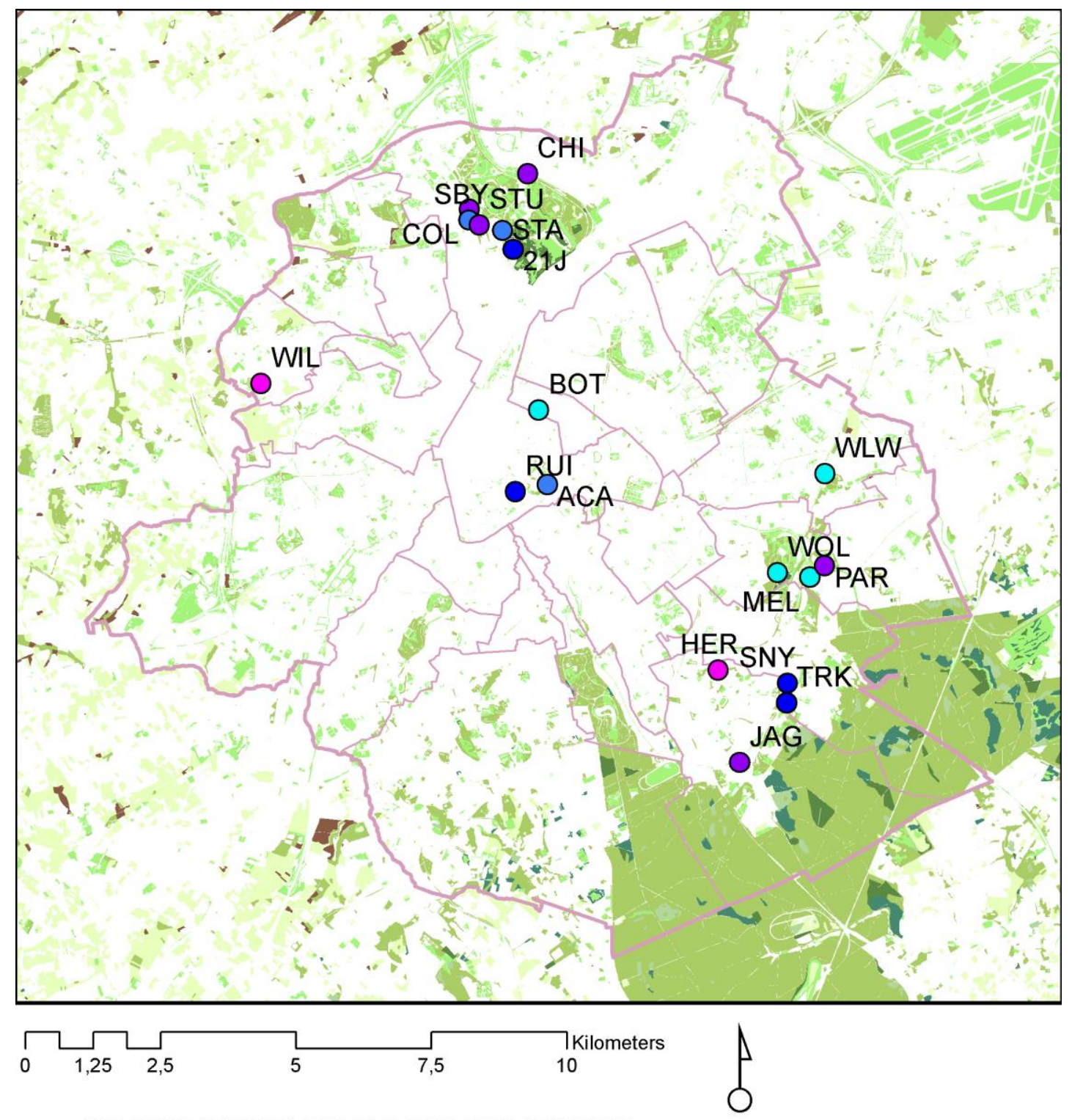

GREEN SPACE TYPES AND TREE POLLEN ALLERGY RISK

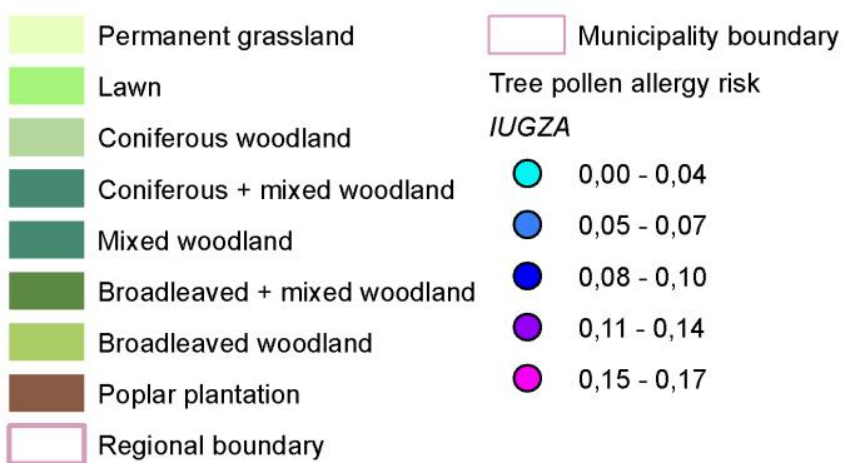

Fig. 1. Green space typology in Brussels Capital Region, Belgium, and location of the 18 urban green spaces that were included in the study, with an indication of their average baseline tree pollen allergy risk $\left(I_{U G Z A}\right)$ 


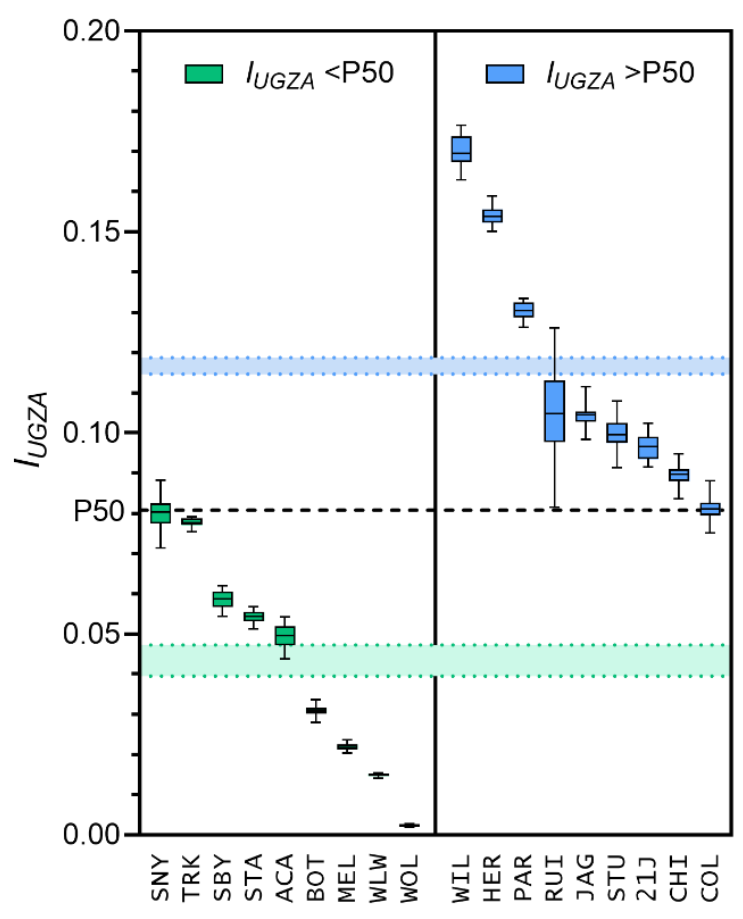

Fig. 2. Tree pollen allergy risk $\left(I_{U G Z A}\right)$ in 18 urban green spaces in the Brussels Capital Region, Belgium. Urban green spaces were stratified in two groups: green spaces with average baseline $I_{U G Z A}$ below vs. above the overall median $\left(\mathrm{P} 50 I_{U G Z A}=0.081\right)$. Shaded intervals indicate the $95 \%$ CIs for $I_{U G Z A}$ subgroup means. 


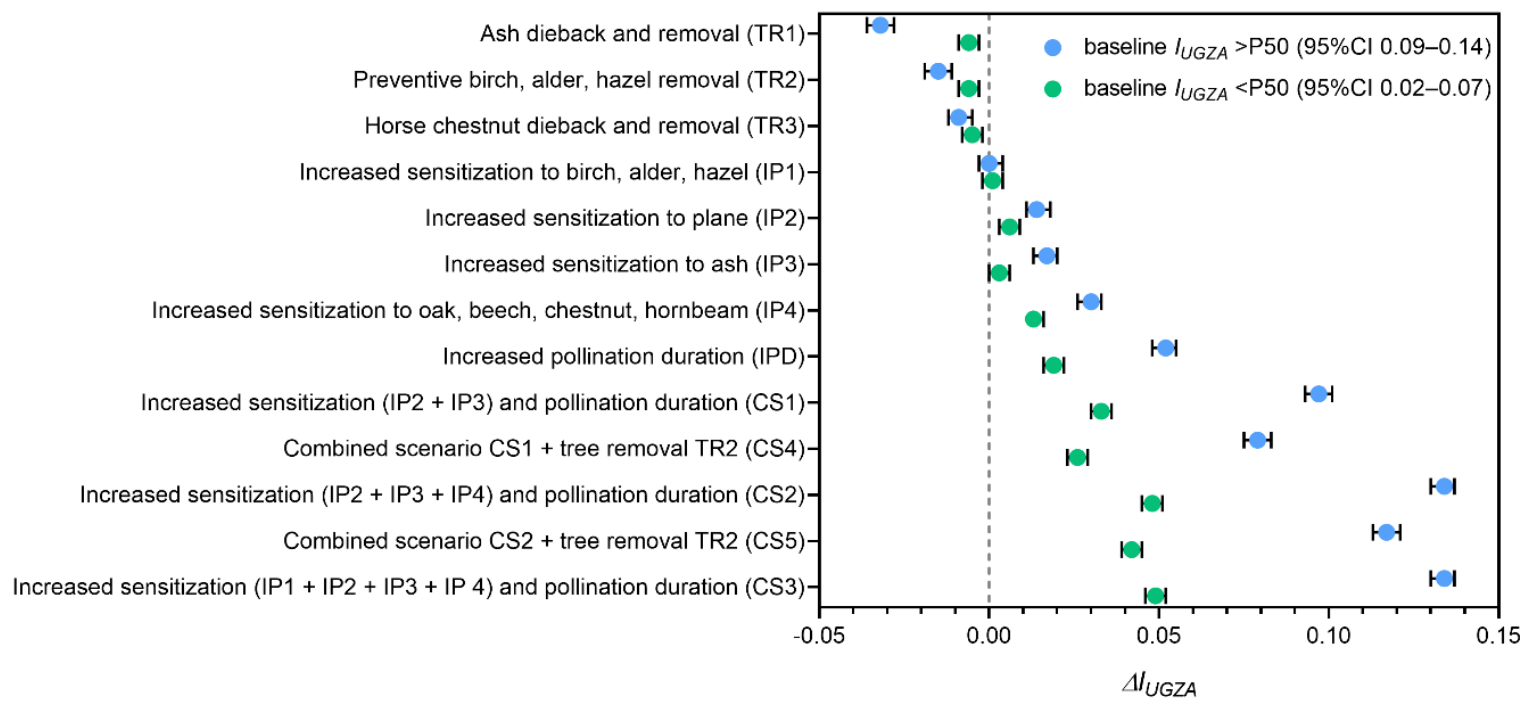

Fig. 3. Changes in tree pollen allergy risk $\left(\triangle I_{U G Z A}\right)$ in urban green spaces in Brussels Capital Region, Belgium, across green space intervention, allergic sensitization and pollination duration change scenarios. Urban green spaces were stratified in two groups: green spaces with average baseline $I_{U G Z A}$ below vs. above the overall median (median $\left.I_{U G Z A}=0.08\right) . \Delta I_{U G Z A}$ (average and $95 \% \mathrm{CI}$ ) is calculated as the estimated difference between the marginal mean $I_{U G Z A}$ of the scenario and the subgroup mean baseline $I_{U G Z A}$. 


\section{List of appendices}

Appendix A. Conceptual model of the urban green zone allergenicity index $\left(I_{U G Z A}\right)$ method Appendix B. Characteristics of urban green spaces

Appendix C. Allergenic potential, pollination syndrome and pollen season duration of allergenic tree species

Appendix D. Tree pollen allergy risk in 18 urban green spaces in Brussels

Appendix E. Relative change (\%) in tree pollen allergy risk in 18 urban green spaces 


\section{Appendix A. Conceptual model of the urban green zone allergenicity}

index $\left(I_{U G Z A}\right)$ method

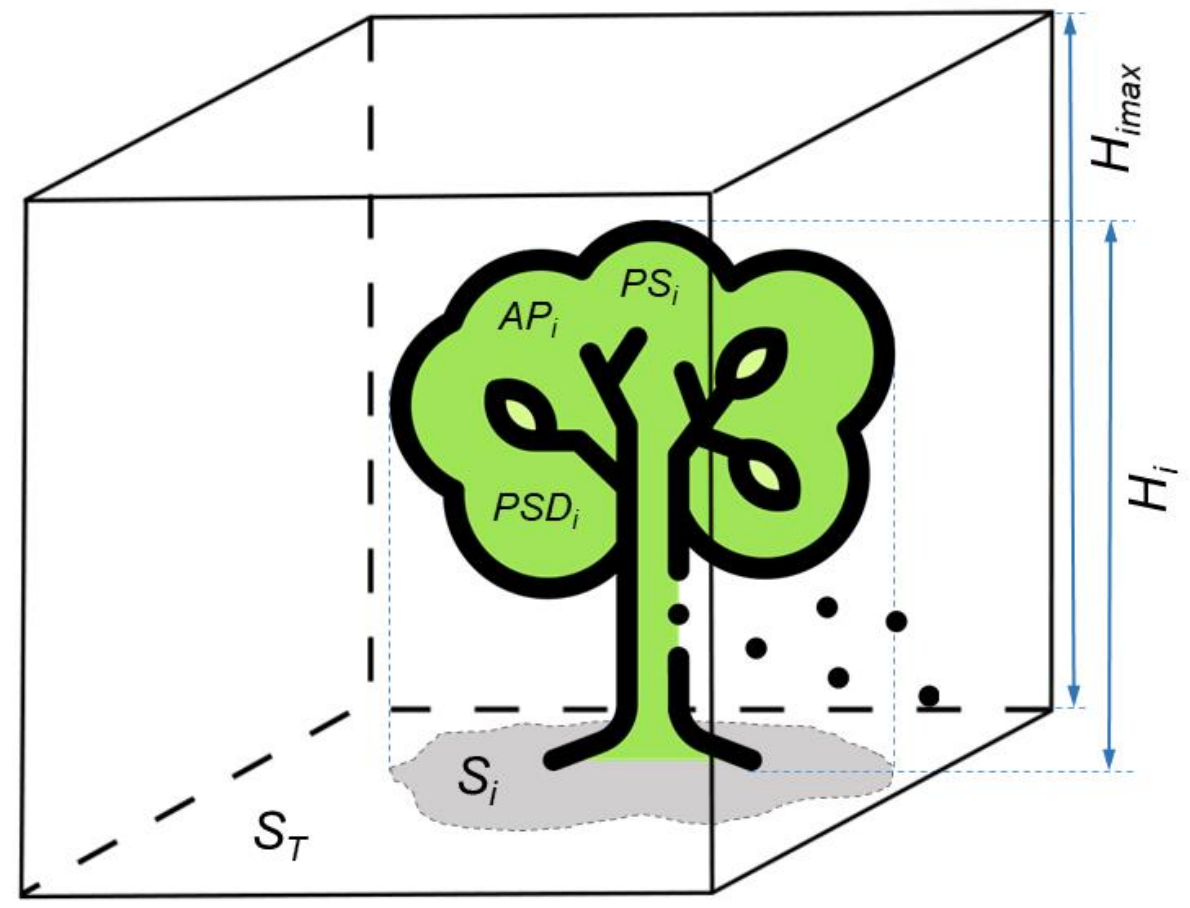

Fig. S1. Assessment of urban green space tree pollen allergy risk with the urban green zone allergenicity index $\left(I_{U G Z A}\right)$ method. The maximum volume that can be occupied by allergenic trees is defined by the surface area of the green space $S_{T}$ and the maximum tree height $H_{\text {imax }}$ (in this study $H_{\text {imax }}=30 \mathrm{~m}$ ). $I_{U G Z A}$ is determined by the allergenic potential $A P_{i}$, pollination syndrome $P S_{i}$, pollen season duration $P S D_{i}$, tree height $H_{i}$ and vertical crown projection area $S_{i}$ of all trees in the green space. $I_{U G Z A}$ can be interpreted as the proportion of the volume that is occupied by trees that emit allergenic pollen, or as the relative tree pollen allergy risk compared to a homogeneous birch forest with $100 \%$ crown cover and a canopy height of $30 \mathrm{~m}$. 


\section{Appendix B. Characteristics of urban green spaces}

Table S1. Characteristics of 18 urban green spaces in the Brussels Capital Region, Belgium, that were included in the study

\begin{tabular}{|c|c|c|c|c|c|c|c|c|c|}
\hline \multirow[b]{2}{*}{ ID } & \multirow[b]{2}{*}{ Name } & \multirow[b]{2}{*}{$\begin{array}{l}\text { Area } \\
\text { (ha) }\end{array}$} & \multirow[b]{2}{*}{$N_{\text {trees }}$} & \multirow[b]{2}{*}{$N_{\text {taxa }}$} & \multirow[b]{2}{*}{$\begin{array}{l}\text { Tree } \\
\text { density } \\
\text { (trees/ha) }\end{array}$} & \multicolumn{3}{|c|}{ Medians and IQR } & \multirow[b]{2}{*}{$\begin{array}{l}\text { Dominant taxa } \\
\text { (proportion of } \\
\text { trees) }\end{array}$} \\
\hline & & & & & & $\begin{array}{l}\mathrm{CBH}_{150} \\
(\mathrm{~cm})\end{array}$ & $\begin{array}{l}H \\
(\mathrm{~m})\end{array}$ & $\begin{array}{l}\mathrm{D}_{\text {crown }} \\
\text { (m) }\end{array}$ & \\
\hline $21 \mathrm{~J}$ & $\begin{array}{l}\text { Square du } 21 \\
\text { juillet } \\
21 \text { juli-square }\end{array}$ & 1.39 & 132 & 19 & 95 & $\begin{array}{l}170 \\
(107)\end{array}$ & $\begin{array}{l}15 \\
(16)\end{array}$ & $10(8)$ & $\begin{array}{l}\text { Taxus baccata } \\
(0.42), \text { Aesculus } \\
\text { hippocastanum } \\
(0.21)\end{array}$ \\
\hline ACA & $\begin{array}{l}\text { Palais des } \\
\text { Académies } \\
\text { Academieënpaleis }\end{array}$ & 0.54 & 75 & 27 & 139 & $\begin{array}{l}75 \\
(157)\end{array}$ & $\begin{array}{l}8 \\
(10)\end{array}$ & $5(9)$ & $\begin{array}{l}\text { Taxus baccata } \\
(0.27), \text { Aesculus } \\
\text { hippocastanum } \\
(0.17)\end{array}$ \\
\hline BOT & $\frac{\text { Jardin Botanique }}{\text { Kruidtuin }}$ & 3.99 & 826 & 212 & 207 & $53(74)$ & $\begin{array}{l}5 \\
(6)\end{array}$ & $4(4)$ & $\begin{array}{l}\text { Tilia tomentosa } \\
(0.07), \text { Ilex } \\
\text { aquifolium (0.06), } \\
\text { Taxus baccata } \\
(0.05), \text { Magnolia } \\
\text { grandiflora (0.04) }\end{array}$ \\
\hline CHI & $\begin{array}{l}\text { Jardin du Pavillon } \\
\underline{\text { chinois }} \\
\text { Tuin van het } \\
\text { Chinees Paviljoen }\end{array}$ & 3.11 & 307 & 51 & 99 & $\begin{array}{l}146 \\
(84)\end{array}$ & $\begin{array}{l}20 \\
(10)\end{array}$ & $10(6)$ & $\begin{array}{l}\text { Pinus nigra } \\
(0.16), \text { Taxus } \\
\text { baccata (0.08), } \\
\text { Acer } \\
\text { pseudoplatanus } \\
(0.08)\end{array}$ \\
\hline $\mathrm{COL}$ & $\begin{array}{l}\underline{\text { Jardin Colonial de }} \\
\underline{\text { Laeken }} \\
\text { Koloniale Tuin }\end{array}$ & 2.21 & 481 & 31 & 218 & $\begin{array}{l}129 \\
(80)\end{array}$ & $\begin{array}{l}16 \\
(10)\end{array}$ & $8(4)$ & $\begin{array}{l}\text { Taxus baccata } \\
(0.46), \text { Pinus } \\
\text { nigra }(0.16), \\
\text { Fraxinus } \\
\text { excelsior }(0.09)\end{array}$ \\
\hline HER* & $\begin{array}{l}\underline{\text { Parc de la }} \\
\underline{\text { Héronnière }} \\
\text { Reigerbospark }\end{array}$ & 4.48 & 657 & 35 & 147 & $\begin{array}{l}129 \\
(50)\end{array}$ & $\begin{array}{l}20 \\
(7)\end{array}$ & $13(6)$ & $\begin{array}{l}\text { Acer } \\
\text { pseudoplatanus } \\
(0.44), \text { Salix alba } \\
(0.21), \text { Fraxinus } \\
\text { excelsior }(0.10)\end{array}$ \\
\hline $\mathrm{JAG}^{*}$ & $\frac{\text { Parc du Jagersveld }}{\text { Jagersveldpark }}$ & 2.58 & 273 & 43 & 106 & $\begin{array}{l}160 \\
(107)\end{array}$ & $\begin{array}{l}19 \\
(11)\end{array}$ & $10(8)$ & $\begin{array}{l}\text { Taxus baccata } \\
(0.38), \text { Pinus } \\
\text { nigra (0.06), } \\
\text { Carpinus betulus }\end{array}$ \\
\hline
\end{tabular}




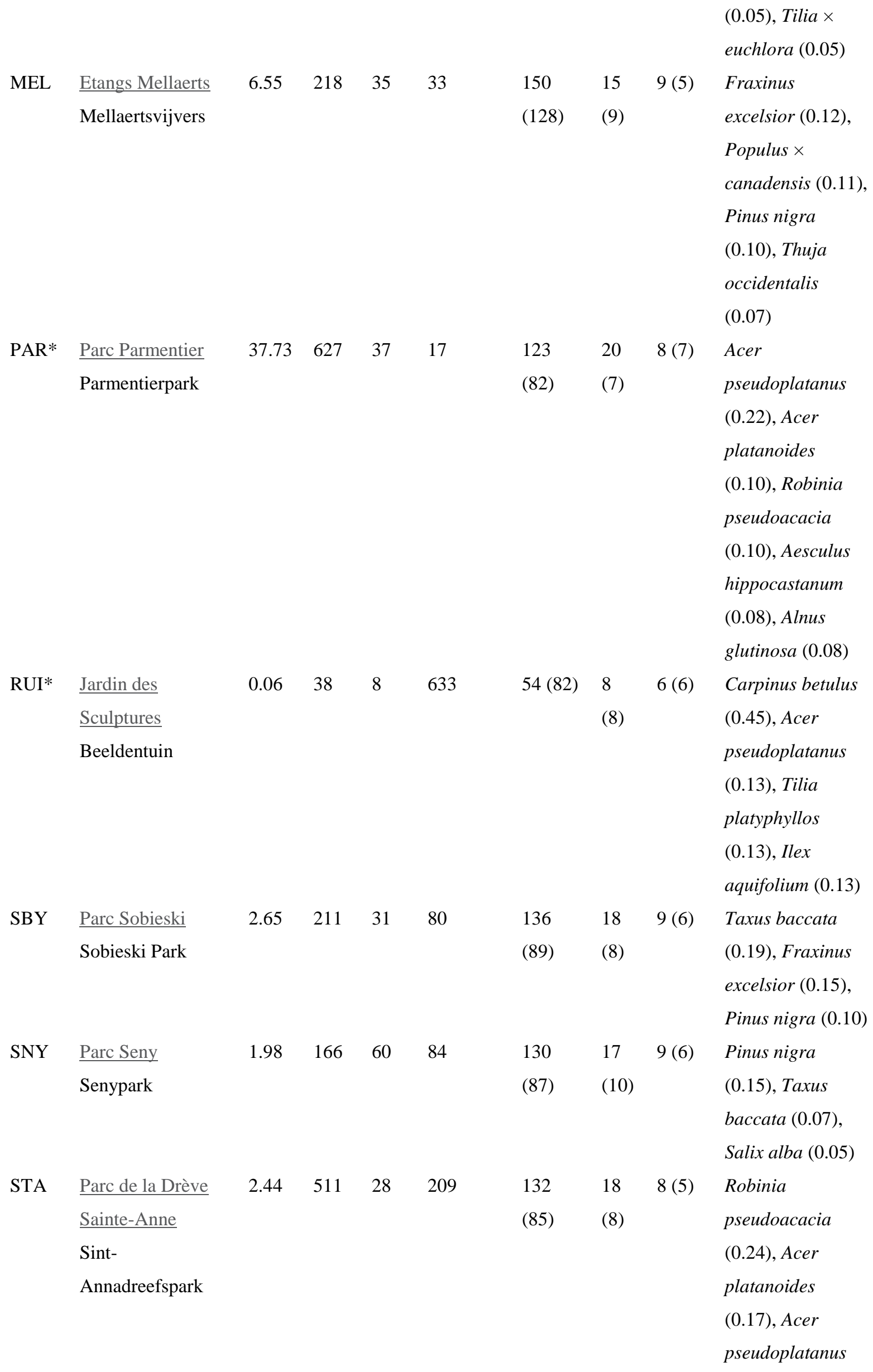




\begin{tabular}{|c|c|c|c|c|c|c|c|c|c|}
\hline & & & & & & & & & $\begin{array}{l}(0.15), \text { Tilia } \\
\text { platyphyllos } \\
(0.10), \text { Ulmus } \\
\text { minor }(0.10)\end{array}$ \\
\hline \multirow[t]{7}{*}{ STU* } & $\begin{array}{l}\text { Jardins du fleuriste } \\
\underline{\text { de Stuyvenberg }}\end{array}$ & 1.15 & 295 & 18 & 257 & $\begin{array}{l}125 \\
(89)\end{array}$ & $\begin{array}{l}18 \\
(7)\end{array}$ & $7(5)$ & $\begin{array}{l}\text { Acer } \\
\text { pseudoplatanus }\end{array}$ \\
\hline & Tuinen van de & & & & & & & & $(0.27)$, Robinia \\
\hline & bloemist van & & & & & & & & pseudoacacia \\
\hline & Stuyvenberg & & & & & & & & (0.19), Taxus \\
\hline & & & & & & & & & baccata (0.11), \\
\hline & & & & & & & & & Ilex aquifolium \\
\hline & & & & & & & & & $(0.10)$ \\
\hline \multirow[t]{7}{*}{ TRK } & $\underline{\text { Parc de l'Etang }}$ & 6.10 & 373 & 57 & 61 & 150 & 23 & $12(6)$ & Tilia $\times$ euchlora \\
\hline & $\underline{\text { Ten Reuken }}$ & & & & & (104) & $(10)$ & & $(0.08)$, Acer \\
\hline & Tenreuken park & & & & & & & & pseudoplatanus \\
\hline & & & & & & & & & $(0.08)$, Taxus \\
\hline & & & & & & & & & baccata (0.07), \\
\hline & & & & & & & & & Acer platanoides \\
\hline & & & & & & & & & $(0.07)$ \\
\hline \multirow[t]{7}{*}{ WIL* } & $\underline{\text { Bois de Wilder }}$ & 6.25 & 645 & 29 & 103 & 133 & 20 & $10(7)$ & Fraxinus \\
\hline & Wilderbos & & & & & (77) & (9) & & excelsior (0.27), \\
\hline & & & & & & & & & Acer \\
\hline & & & & & & & & & pseudoplatanus \\
\hline & & & & & & & & & (0.14), Populus $\times$ \\
\hline & & & & & & & & & canadensis (0.09), \\
\hline & & & & & & & & & Salix alba (0.08) \\
\hline \multirow[t]{4}{*}{ WLW } & $\underline{\text { Parc Malou }}$ & 14.99 & 63 & 8 & 4 & 249 & 26 & $15(8)$ & Populus $\times$ \\
\hline & Maloupark & & & & & $(124)$ & (9) & & canadensis (0.75), \\
\hline & & & & & & & & & Fraxinus \\
\hline & & & & & & & & & excelsior $(0.10)$ \\
\hline \multirow[t]{3}{*}{ WOL } & $\underline{\text { Parc de Woluwe }}$ & 29.09 & $42 *$ & 15 & 1 & 155 & 23 & $8(7)$ & Acer platanoides \\
\hline & Woluwepark & & & & & $(76)$ & (6) & & (0.19), Betula \\
\hline & & & & & & & & & pendula (0.14) \\
\hline
\end{tabular}

IQR: interquartile range; $N_{\text {trees }}$ : number of trees ; $N_{\text {taxa }}$ : number of taxa (species, subspecies, cultivars and trees identified at genus level); $C B H_{150}$ : stem circumference at $150 \mathrm{~cm}$ above ground; $H$ : tree height; $D_{\text {crown }}$ : crown diameter; *The allergy risk is considered moderate in a number of change scenarios (CS2-5). 


\section{Appendix C. Allergenic potential, pollination syndrome and pollen season duration of allergenic tree species}

Table S2. Allergenic potential, pollination syndrome and pollen season duration of allergenic tree species recorded in 18 urban green spaces in the Brussels Capital Region, Belgium

\begin{tabular}{|c|c|c|c|c|c|}
\hline Species & Vernacular name & Family & $\begin{array}{l}\text { Allergenic potential } \\
(A P)\end{array}$ & $\begin{array}{l}\text { Pollination syndrome } \\
(P S)\end{array}$ & $\begin{array}{l}\text { Pollen season duration } \\
(P S D)\end{array}$ \\
\hline Aesculus hippocastanum & horse-chestnut & Sapindaceae & 1 & 2 & 2 \\
\hline other Aesculus spp. & horse-chestnut & Sapindaceae & 1 & 2 & 2 \\
\hline Alnus glutinosa & black alder & Betulaceae & 4 & 3 & 2 \\
\hline Alnus incana & grey alder & Betulaceae & 4 & 3 & 2 \\
\hline other Alnus spp. & alder & Betulaceae & 3 & 3 & 2 \\
\hline Betula pendula & silver birch & Betulaceae & 4 & 3 & 3 \\
\hline other Betula spp. & birch & Betulaceae & 3 & 3 & 2 \\
\hline Carpinus betulus & common hornbeam & Betulaceae & 2 & 3 & 1 \\
\hline other Carpinus spp. & hornbeam & Betulaceae & 2 & 3 & 1 \\
\hline Castanea sativa & chestnut & Fagaceae & 1 & 3 & 2 \\
\hline Corylus avellana & common hazel & Betulaceae & 4 & 3 & 3 \\
\hline Corylus colurna & Turkish hazel & Betulaceae & 3 & 3 & 3 \\
\hline Fagus sylvatica & common beech & Fagaceae & 1 & 2 & 3 \\
\hline Fraxinus excelsior & common ash & Oleaceae & 2 & 3 & 2 \\
\hline other Fraxinus spp. & ash & Oleaceae & 2 & 3 & 2 \\
\hline Larix decidua & European larch & Pinaceae & 1 & 3 & 1 \\
\hline Ligustrum spp. & privet & Oleaceae & 1 & 2 & 2 \\
\hline
\end{tabular}




\begin{tabular}{lllll} 
Olea europaea & olive & Oleaceae & 1 & 3 \\
Platanus spp. & plane & Platanaceae & 1 & 3 \\
Populus spp. & poplar & Salicaceae & 1 & 2 \\
Quercus petraea & sessile oak & Fagaceae & 2 & 3 \\
Quercus robur & common oak & Fagaceae & 2 & 3 \\
other Quercus spp. & oak & Fagaceae & 2 & 3 \\
Salix spp. & willow & Salicaceae & 1 & 2 \\
Tilia cordata & small-leaved lime & Malvaceae & 1 & 2 \\
Tilia platyphyllos & large-leaved lime & Malvaceae & 1 & 2 \\
Tilia tomentosa & silver lime & Malvaceae & 1 & 2 \\
Tilia $\times$ euchlora & Crimean lime & Malvaceae & 1 & 2 \\
other Tilia spp. & lime & Malvaceae & 1 & 2 \\
Ulmus minor & field elm & Ulmaceae & 1 & 2 \\
other Ulmus spp. & elm & Ulmaceae & 1 & 2 \\
Other species (not allergenic) & & 0 & 3 \\
\hline
\end{tabular}

Allergenic potential (AP): 0, non-allergenic; 1, low allergenicity; 2, moderate allergenicity; 3, high allergenicity; 4, main local allergen

Pollination syndrome (PS): 2, amphiphilous (insect- or wind-pollinated); 3, anemophilous (wind-pollinated)

Pollen season duration (PSD): 1, 1-3 weeks; 2, 4-6 weeks; 3, more than 6 weeks 


\section{Appendix D. Tree pollen allergy risk in 18 urban green spaces in Brussels}

Table S3. Tree pollen allergy risk in 18 urban green spaces $\left(I_{U G Z A}\right)$ in the Brussels Capital Region, Belgium, across green space intervention, allergenic potential and pollination duration change scenarios.

\begin{tabular}{|c|c|c|c|c|c|c|c|c|c|c|c|c|c|c|}
\hline \multirow{3}{*}{$\begin{array}{l}\text { Green } \\
\text { space ID }\end{array}$} & \multirow{3}{*}{$\begin{array}{l}\text { Baseline } \\
I_{U G Z A}\end{array}$} & \multicolumn{13}{|c|}{ Scenario $I_{U G Z A}{ }^{\mathrm{a}}$} \\
\hline & & TR1 & TR2 & TR3 & IP1 & IP2 & IP3 & IP4 & IPD & CS1 & $\mathrm{CS} 2$ & $\mathrm{CS} 3$ & $\mathrm{CS} 4$ & CS5 \\
\hline & & & & & & & & & & & & & & \\
\hline $21 \mathrm{~J}$ & 0.096 & 0.078 & 0.096 & 0.051 & 0.097 & 0.095 & 0.106 & 0.116 & 0.144 & 0.156 & 0.181 & 0.180 & 0.157 & 0.185 \\
\hline $\mathrm{ACA}$ & 0.050 & 0.050 & 0.051 & 0.032 & 0.051 & 0.059 & 0.049 & 0.094 & 0.065 & 0.078 & 0.121 & 0.121 & 0.080 & 0.120 \\
\hline BOT & 0.031 & 0.025 & 0.027 & 0.028 & 0.031 & 0.038 & 0.033 & 0.039 & 0.046 & 0.061 & 0.072 & 0.073 & 0.056 & 0.069 \\
\hline $\mathrm{CHI}$ & 0.089 & 0.061 & 0.076 & 0.085 & 0.091 & 0.096 & 0.103 & 0.127 & 0.128 & 0.155 & 0.199 & 0.202 & 0.144 & 0.184 \\
\hline $\mathrm{COL}$ & 0.081 & 0.037 & 0.081 & 0.071 & 0.081 & 0.082 & 0.104 & 0.116 & 0.115 & 0.149 & 0.185 & 0.185 & 0.149 & 0.185 \\
\hline HER & 0.154 & 0.103 & 0.115 & 0.148 & 0.153 & 0.157 & 0.181 & 0.173 & 0.219 & 0.259 & 0.283 & 0.285 & 0.216 & 0.238 \\
\hline JAG & 0.104 & 0.086 & 0.097 & 0.102 & 0.103 & 0.149 & 0.112 & 0.148 & 0.152 & 0.232 & 0.288 & 0.281 & 0.222 & 0.279 \\
\hline MEL & 0.022 & 0.018 & 0.019 & 0.019 & 0.021 & 0.024 & 0.023 & 0.026 & 0.031 & 0.038 & 0.042 & 0.043 & 0.035 & 0.040 \\
\hline PAR & 0.130 & 0.108 & 0.106 & 0.120 & 0.131 & 0.149 & 0.142 & 0.175 & 0.190 & 0.237 & 0.296 & 0.298 & 0.204 & 0.262 \\
\hline RUI & 0.105 & 0.105 & 0.101 & 0.104 & 0.104 & 0.160 & 0.104 & 0.117 & 0.164 & 0.251 & 0.269 & 0.272 & 0.240 & 0.269 \\
\hline SBY & 0.059 & 0.027 & 0.049 & 0.056 & 0.059 & 0.059 & 0.074 & 0.065 & 0.086 & 0.110 & 0.119 & 0.122 & 0.098 & 0.109 \\
\hline SNY & 0.080 & 0.076 & 0.050 & 0.078 & 0.083 & 0.101 & 0.082 & 0.095 & 0.109 & 0.144 & 0.161 & 0.165 & 0.111 & 0.131 \\
\hline STA & 0.054 & 0.046 & 0.055 & 0.039 & 0.054 & 0.057 & 0.059 & 0.055 & 0.084 & 0.095 & 0.096 & 0.096 & 0.094 & 0.097 \\
\hline STU & 0.100 & 0.045 & 0.100 & 0.098 & 0.100 & 0.101 & 0.129 & 0.130 & 0.150 & 0.193 & 0.229 & 0.232 & 0.188 & 0.229 \\
\hline TRK & 0.078 & 0.076 & 0.073 & 0.078 & 0.079 & 0.088 & 0.079 & 0.118 & 0.115 & 0.132 & 0.182 & 0.181 & 0.123 & 0.173 \\
\hline WIL & 0.170 & 0.119 & 0.122 & 0.171 & 0.170 & 0.172 & 0.199 & 0.196 & 0.232 & 0.273 & 0.304 & 0.302 & 0.220 & 0.253 \\
\hline WLW & 0.015 & 0.014 & 0.015 & 0.015 & 0.015 & 0.015 & 0.015 & 0.015 & 0.022 & 0.023 & 0.024 & 0.023 & 0.023 & 0.023 \\
\hline WOL & 0.002 & 0.002 & 0.001 & 0.002 & 0.002 & 0.002 & 0.002 & 0.003 & 0.003 & 0.003 & 0.003 & 0.004 & 0.002 & 0.002 \\
\hline
\end{tabular}


Tree removal scenarios: TR1, Ash dieback and removal; TR2, Preventive birch, alder and hazel removal; TR3, Horse-chestnut dieback and removal

Increased sensitization scenarios: IP1, Increased allergenic potential of birch, alder, and hazel; IP2, Increased allergenic potential of plane; IP3, Increased allergenic potential of ash; IP4, Increased allergenic potential of oak, beech, chestnut, and hornbeam

IPD, Increased pollination duration

Combined scenarios: CS1: IP2+IP3+IPD; CS2: IP2+IP3+IP4+IPD; CS3: IP1+IP2+IP3+IP4+IPD; CS4: IP2+IP3+IPD+TR2; CS5: IP2+IP3+IP4+IPD+TR2

et al., 


\section{Appendix F. Relative change (\%) in tree pollen allergy risk in 18 urban green spaces}

Table S4. Relative change (\%) in tree pollen allergy risk in 18 urban green spaces $\left(I_{U G Z A}\right)$ in the Brussels Capital Region, Belgium, across green space intervention, allergenic potential and pollination duration change scenarios.

\begin{tabular}{|c|c|c|c|c|c|c|c|c|c|c|c|c|c|c|}
\hline \multirow{3}{*}{$\begin{array}{l}\text { Green } \\
\text { space ID }\end{array}$} & \multirow{3}{*}{$\begin{array}{l}\text { Baseline } \\
I_{U G Z A}\end{array}$} & \multicolumn{13}{|c|}{ Relative change per scenario $(\%)^{\mathrm{a}}$} \\
\hline & & TR1 & TR2 & TR3 & IP1 & IP2 & IP3 & IP4 & IPD & $\mathrm{CS} 1$ & $\mathrm{CS} 2$ & $\mathrm{CS} 3$ & $\mathrm{CS} 4$ & CS5 \\
\hline & & & & & & & & & & & & & & \\
\hline $21 \mathrm{~J}$ & 0.096 & -18.7 & -0.6 & -46.7 & +1.0 & -1.3 & +10.3 & +20.4 & +49.0 & +61.7 & +88.2 & +87.4 & +62.9 & +91.8 \\
\hline $\mathrm{ACA}$ & 0.050 & +0.8 & +3.1 & -34.9 & +2.4 & +18.5 & -0.3 & +89.9 & +30.9 & +56.7 & +144.5 & +144.2 & +61.1 & +142.9 \\
\hline BOT & 0.031 & -18.5 & -12.9 & -8.6 & +0.6 & +23.4 & +6.9 & +27.8 & +48.3 & +97.7 & +134.8 & +138.1 & +83.6 & +125.3 \\
\hline $\mathrm{CHI}$ & 0.089 & -31.3 & -14.6 & -4.4 & +1.8 & +7.2 & +15.7 & +41.7 & +43.1 & +72.8 & +122.5 & +126.2 & +61.0 & +105.7 \\
\hline $\mathrm{COL}$ & 0.081 & -54.6 & -0.3 & -12.0 & +0.6 & +0.9 & +28.0 & +43.7 & +42.3 & +83.3 & +128.6 & +128.1 & +83.6 & +128.4 \\
\hline HER & 0.154 & -32.9 & -25.3 & -3.7 & -0.5 & +1.6 & +17.5 & +12.5 & +42.4 & +68.2 & +83.5 & +84.9 & +40.2 & +54.5 \\
\hline JAG & 0.104 & -17.7 & -7.2 & -2.5 & -1.0 & +43.3 & +7.8 & +42.3 & +45.7 & +122.0 & +176.4 & +169.6 & +112.6 & +168.0 \\
\hline MEL & 0.022 & -16.7 & -14.0 & -10.6 & -2.0 & +12.2 & +5.9 & +19.9 & +42.4 & +75.1 & +94.9 & +96.8 & +59.1 & +81.5 \\
\hline PAR & 0.130 & -17.0 & -18.3 & -8.3 & +0.6 & +13.9 & +8.6 & +34.1 & +46.0 & +81.6 & +127.3 & +128.3 & +56.3 & +101.3 \\
\hline RUI & 0.105 & +0.2 & -4.2 & -1.0 & -0.8 & +52.7 & -1.1 & +11.2 & +56.2 & +139.1 & +156.1 & +159.6 & +128.4 & +156.5 \\
\hline SBY & 0.059 & -53.5 & -15.7 & -4.7 & +1.3 & +0.9 & +26.8 & +11.4 & +47.0 & +88.3 & +102.1 & +108.0 & +67.8 & +85.2 \\
\hline SNY & 0.080 & -5.0 & -37.2 & -2.6 & +3.7 & +26.3 & +2.9 & +18.7 & +36.0 & +79.4 & +100.7 & +106.2 & +38.1 & +63.2 \\
\hline STA & 0.054 & -14.6 & +1.0 & -28.7 & +0.0 & +5.5 & +8.1 & +2.2 & +54.4 & +74.3 & +77.7 & +76.3 & +73.1 & +78.2 \\
\hline STU & 0.100 & -54.9 & +0.7 & -1.8 & +0.8 & +0.9 & +29.2 & +30.3 & +50.3 & +93.6 & +129.5 & +132.5 & +88.7 & +130.2 \\
\hline TRK & 0.078 & -2.3 & -6.7 & +0.6 & +1.4 & +12.9 & +1.5 & +52.1 & +47.7 & +69.3 & +133.9 & +133.1 & +58.1 & +122.9 \\
\hline WIL & 0.170 & -30.0 & -28.4 & +0.8 & -0.1 & +0.9 & +16.7 & +14.9 & +36.6 & +60.3 & +78.9 & +77.8 & +29.1 & +48.8 \\
\hline WLW & 0.015 & -3.4 & -0.3 & -0.1 & +0.9 & +2.2 & +1.8 & +1.8 & +49.8 & +56.9 & +59.4 & +58.0 & +56.3 & +58.1 \\
\hline WOL & 0.002 & -3.6 & -55.0 & +3.8 & +3.1 & +0.3 & +3.1 & +10.8 & +24.4 & +26.5 & +51.6 & +54.6 & -28.6 & -4.7 \\
\hline
\end{tabular}


Tree removal scenarios: TR1, Ash dieback and removal; TR2, Preventive birch, alder and hazel removal; TR3, Horse-chestnut dieback and removal

Increased sensitization scenarios: IP1, Increased allergenic potential of birch, alder, and hazel; IP2, Increased allergenic potential of plane; IP3, Increased allergenic potential of ash; IP4, Increased allergenic potential of oak, beech, chestnut, and hornbeam

IPD, Increased pollination duration

Combined scenarios: CS1: IP2+IP3+IPD; CS2: IP2+IP3+IP4+IPD; CS3: IP1+IP2+IP3+IP4+IPD; CS4: IP2+IP3+IPD+TR2; CS5: IP2+IP3+IP4+IPD+TR2 


\section{Acknowledgments}

The authors acknowledge Leefmilieu Brussel/Bruxelles Environnement for providing green space tree data. The tree icon in the supplementary material and the icons in the graphical abstract were made by Freepik from www.flaticon.com and is used under a Flaticon Basic License (with attribution).

\section{Declaration of competing interest}

The authors declare that they have no known competing financial interests or personal relationships that could have appeared to influence the work reported in this paper.

\section{Ethical clearance}

The protocol for this study did not require ethics approval.

\section{CRediT author statement}

Raf Aerts: Methodology, Formal analysis, Data Curation, Writing - Original Draft, Writing Review \& Editing, Visualization. Nicolas Bruffaerts: Conceptualization, Validation, Writing - Original Draft, Writing - Review \& Editing, Project Administration, Funding Acquisition.

Ben Somers: Resources, Writing - Review \& Editing. Claire Demoury: Writing - Review \& Editing, Supervision. Michelle Plusquin: Writing - Review \& Editing, Supervision. Tim S. Nawrot: Writing - Review \& Editing, Supervision. Marijke Hendrickx: Writing - Review \& Editing, Supervision, Funding Acquisition 